\title{
Excavations at Maybury Park, Edinburgh (1990-2)
}

\author{
by Colm Moloney* and John A Lawson $\dagger$
}

*Headland Archaeology Ltd, Unit 4b, Europa Enterprise Park, Midelton, County Cork, Ireland

$\dagger$ City of Edinburgh Council Archaeology Service, Museum of Edinburgh, 142 Canongate, Edinburgh EH8 8DD

\author{
with contributions by \\ Daniel Johnson, Alan Saville, Alison Sheridan, \\ Catherine McGill, Mhairi Hastie and Valerie Dean
}

illustrations by Louise Baker, Jonathan Miller and Marion O’Neil 
Published by the Society of Antiquaries of Scotland, www.socantscot.org.uk with Historic Scotland, www.historic-scotland.gov.uk

Editor and the Council for British Archaeology, www.britarch.ac.uk

Produced by Debra Barrie Archetype Information Technology Ltd, www.archetype-it.com

ISBN: $090390392 \mathrm{X}$

ISSN: $1473-3803$

Requests for permission to reproduce material from a $S A I R$ report should be sent to the Director of the Society of Antiquaries of Scotland, as well as to the author, illustrator, photographer or other copyright holder.

Copyright in any of the Scottish Archaeological Internet Reports series rests with the SAIR Consortium and the individual authors.

The maps are reproduced from Ordnance Survey material with the permission of Ordnance Survey on behalf of The Controller of Her Majesty's Stationery Office. CCrown copyright 2001. Any unauthorized reproduction infringes Crown copyright and may lead to prosecution or civil proceedings. Historic Scotland Licence No GD 03032G, 2002.

The consent does not extend to copying for general distribution, advertising or promotional purposes, the creation of new collective works or resale. 


\section{Contents}

List of illustrations . . . . . . . . . . . . . . . . . . . . . . . . . .

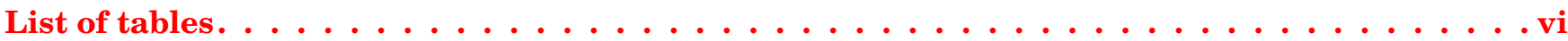

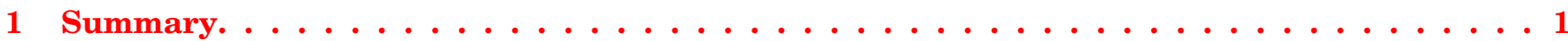

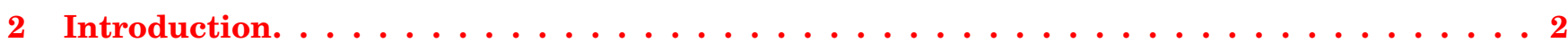

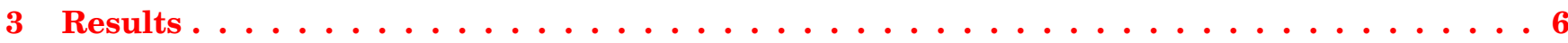

3.1 Evaluation . . . . . . . . . . . . . . . . . . . . . . . . 6

3.2 Excavation . . . . . . . . . . . . . . . . . . . . . . 6

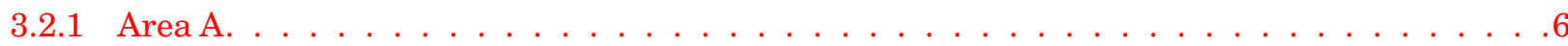

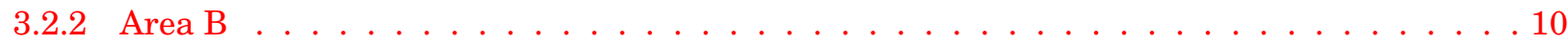

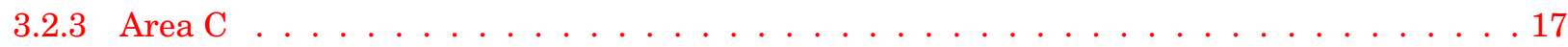

3.2.4 Areas D and E . . . . . . . . . . . . . . . . . . . . . . . . . . . . . .

3.2 .5 Area F. . . . . . . . . . . . . . . . . . . . . . . . . . . . . .

3.2 .6 Area $U \ldots \ldots \ldots \ldots \ldots \ldots$

4 Lithic Artefacts by Alan Saville . . . . . . . . . . . . . . . . . . . . . . . .

4.1 Struck lithic artefacts . . . . . . . . . . . . . . . . . . . . . . . . . . . . 22

4.2 Coarse stone arefacts . . . . . . . . . . . . . . . . . . . . . 23

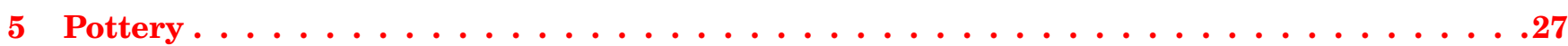

5.1 Pottery of prehistoric and indeterminate date . . . . . . . . . . . . . . . . . 27

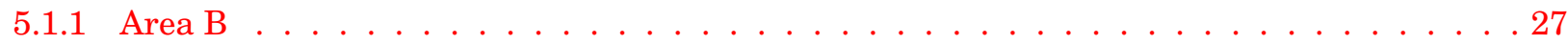

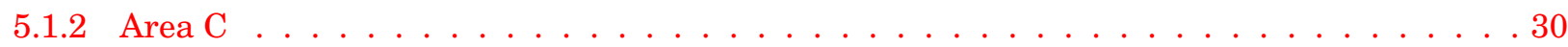

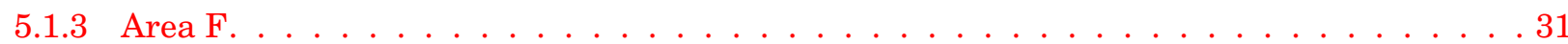

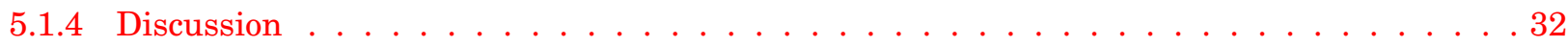

5.2 Post-Roman pottery . . . . . . . . . . . . . . . . . . . . . . 33

5.3 Post-medieval pottery . . . . . . . . . . . . . . . . . . . . . 33

6 The Carbonized Remains by Mhairi Hastie. . . . . . . . . . . . . . . . . . . . . 34

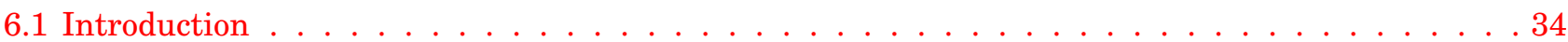

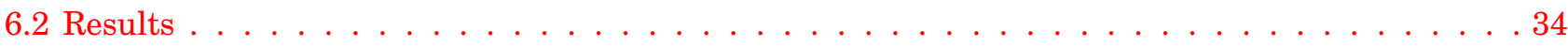

6.2.1 Distribution. . . . . . . . . . . . . . . . . . . . . 34

6.2.2 Cereal remains . . . . . . . . . . . . . . . . . . . . . 34

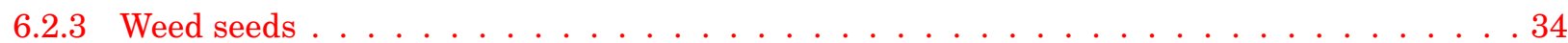

6.2.4 Potential economic species . . . . . . . . . . . . . . . . . . . . . . . 34

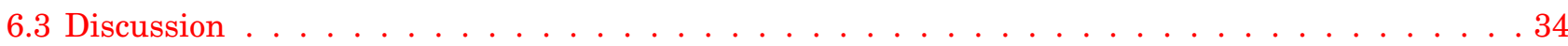

6.3.1 Concentration and distribution . . . . . . . . . . . . . . . . . . . . 34

6.3.2 Plant assemblages . . . . . . . . . . . . . . . . . . . . . 34

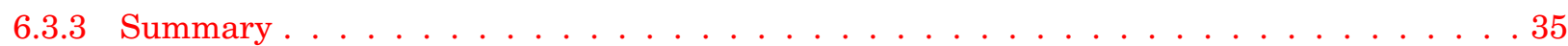


7 Conclusion.

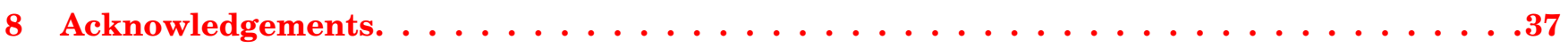

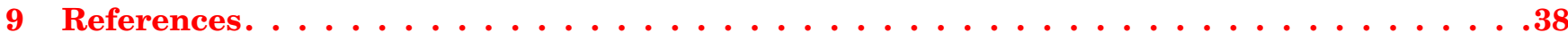




\section{List of illustrations}

Site location, showing test trenches and excavation areas. . . . . . . . . . . . . . Prehistoric/Roman cropmarks in the immediate area of site with the presumed extent of Gogar Loch . . . . . . . . . . . . . . . . . . . . . . . . . . . . . . . . .4 Aerial view of excavated areas (@ RCAHMS) . . . . . . . . . . . . . . . . . . . . .5 Plan of Area A, Phase I . . . . . . . . . . . . . . . . . . . . . . . . . . . . . 6 a, Sections of Features 315 and 325 ; b, Plan and section of Feature $344 \ldots \ldots$. . . . . . . . . .7 Plan of Area A, Phase II . . . . . . . . . . . . . . . . . . . . . . . . . . . . . . . . . . .8 Plan of Area A, Phase III and modern features. . . . . . . . . . . . . . . . . . . . . . . . .9 Aerial view of Areas B, C, D \& E, looking west (C RCAHMS) . . . . . . . . . . . . . . . 10 Plan of Area B, Phase I . . . . . . . . . . . . . . . . . . . . . . . . . . . . . 11

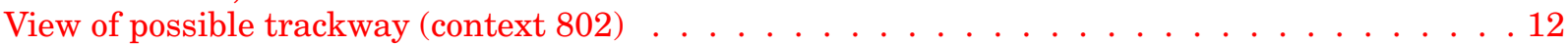
Plan of Area B, Phase II . . . . . . . . . . . . . . . . . . . . . . . . . . . . . . 13 'Banjo-shaped' Feature $620 \ldots \ldots \ldots$. . . . . . . . . . . . . . . . . 14 Hearths 789 and $843 \ldots \ldots \ldots \ldots \ldots \ldots$ Selection of sections from Area B, Phase II . . . . . . . . . . . . . . . . . . . 16

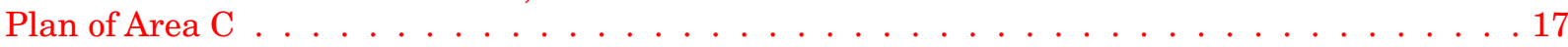
Plan of Area $\mathrm{F} \ldots \ldots \ldots$. . . . . . . . . . . . . . . . . . . . . . . . . . . . 19

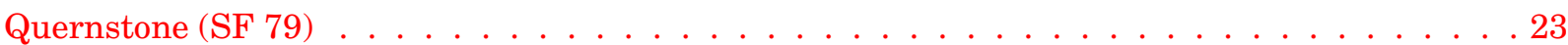
Stone block with two opposed hollows $(\mathrm{SF} 38) \ldots \ldots \ldots \ldots$. . . . . . . . . . . . . . . . . Stone block with hollow (SF 99) . . . . . . . . . . . . . . . . . . . . . . . . 25 Possible mortar (SF 100) . . . . . . . . . . . . . . . . . . . . . . . 26

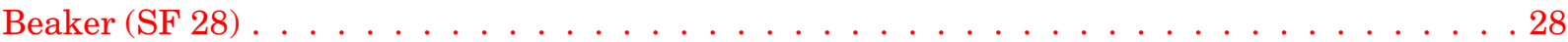
Beaker (SF 28) and stone object (SF 38) in situ . . . . . . . . . . . . . . . . . . 28

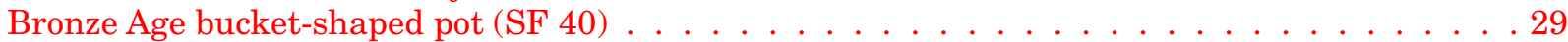
Bucket-shaped pot (SF 40) under excavation . . . . . . . . . . . . . . . . . . . . . . 29 Rimsherd and three body sherds of probable Late Bronze Age coarse pottery . . . . . . . . . . . 30 Probable Late Bronze Age pottery. . . . . . . . . . . . . . . . . . . . . . . . . . 31 Probable Iron Age pottery from Area $\mathrm{F} \ldots \ldots \ldots 31$

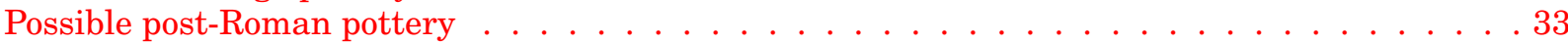




\section{List of tables}

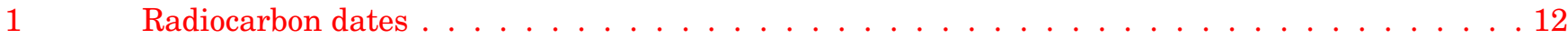

2 Typology and raw material of the struck lithic artefacts. . . . . . . . . . . . . . . . 22

3 Struck lithic artefacts by context . . . . . . . . . . . . . . . . . . . 22 


\section{Summary}

This paper presents the results of a series of excavations carried out by the City of Edinburgh Council Archaeology Service between 1990 and 1992 in advance of the Edinburgh Park development. Following a programme of test excavations, seven areas were opened up for excavation. Three of these contained significant archaeology dating to the Neolithic, Bronze and Iron Ages. The main findings included a Neolithic trackway, evidence for Bronze Age settlement and a large stone-built structure dating to the beginning of the first millennium $\mathrm{AD}$. 


\section{Introduction}

The Edinburgh Park development was undertaken by New Edinburgh Ltd, a joint venture company made up of Miller Developments and Enterprise Edinburgh - Edinburgh City Council's property development company. The development involved the construction of industrial units, office buildings and housing, as well as large-scale landscaping. The Maybury Park investigations (centred on NGR: NT 178720) undertaken by CECAS covered part of the Phase I Edinburgh Park Development, located at South Gyle on the western edge of Edinburgh (illus 1).

The area of investigation was bounded to the west by the Edinburgh City Bypass, to the east by South Gyle Broadway and several recently developed sites and to the south by the West One development. In all, the site was over $1 \mathrm{~km}$ from north to south and $0.5 \mathrm{~km}$ from east to west, with a total area of $66 \mathrm{ha}$. At the time of the excavation, it was bisected from north to south by the Gogar Burn and from east to west by a farm road giving access to Redheughs and Gogar Green Farms, located at the south of the site on either side of the burn; both farms have since been demolished and the site re-landscaped. The geology consisted of fluvio-glacial sands and gravels.

Prior to development the site was characterized by undulating arable farmland forming part of Redheughs Farm. The area to the north of Area $\mathrm{C}$, however, was lower-lying and formed part of the former Gogar Loch which extended eastwards to just south-west of Corstorphine. Geo-technical boreholes sunk by Beattie Watkinson in 1988 across the site of the present-day South Gyle Shopping Centre recorded peat deposits up to $2.50 \mathrm{~m}$ in depth. These deposits, however, remain undated and it is therefore not possible to state at what point during the prehistoric or Early Historic period the loch stopped being a permanent body of open water.

Historic records indicate that the loch has not been a permanent body of open water since the 17th century. Rather, it is described in 1650 as an area 'full of bogs and marshes' (NSA 1845, 245) acting as a natural flood plain for the Gogar Burn. Flooding of this area has been an historic problem as exemplified by Lord James Foresters's petition to Parliament in 1661 which describes the "whole meadow ground and low lying lands...undone by the overflowing Gogar-burne' (NSA 1845). This area still remained susceptible to flooding until the construction of this development which saw the canalization of the Gogar Burn.

The only previously known site or find of archaeological interest within the proposed development site was a small circular cropmark (NGR: NT17SE 21 ), interpreted as a ring-ditch to the north of Gogar Green Farm (illus 2). Chance finds of cists (NGR: NT17SE 4 and NT17SE 20) have been fairly common in the surrounding area although none from within the boundary of the study area. Two Roman camps, Millburn Tower and Gogar Green (NGR: NT17SE 23 and NT17SE 24), have been identified in the area. Sections were excavated through the defensive ditches of the Gogar Green camp in 1980 (Maxwell 1984) in advance of the construction of the City Bypass and it was hoped that the 1990-2 excavations would confirm the eastern extent of this monument. In addition, a possible palisaded enclosure was identified to the south of the site from aerial photographs at Cultins Road (NGR: NT17SE 54). This site was evaluated by CECAS in 1996 (Collard 1996) and the results seemed to support its identification as a multi-ditched enclosure. However, when the southern extent of the site was opened up and excavated in 2002 (Jones 2002) in advance of development, the cropmark was demonstrated to be predominately natural in origin, with the outer ditches formerly excavated by CECAS proving to be part of a series of post-medieval field/enclosure boundary ditches.

Based upon this archaeological evidence, an archaeological evaluation was therefore felt to be necessary by the City of Edinburgh Council in advance of development. Overall management of the project was undertaken by the then City Archaeologist Mark Collard, with the field work managed by Daniel Johnson. The evaluation was undertaken during October and November in 1990, with the results leading onto three main phases of archaeological excavation: Areas A and U, December 1990 and January 1991; Areas B-E, October to December 1991; Area F, January to March 1992 (illus 1; illus 3 ). The following report is based upon the draft data structure report written by Daniel Johnson for CECAS. 


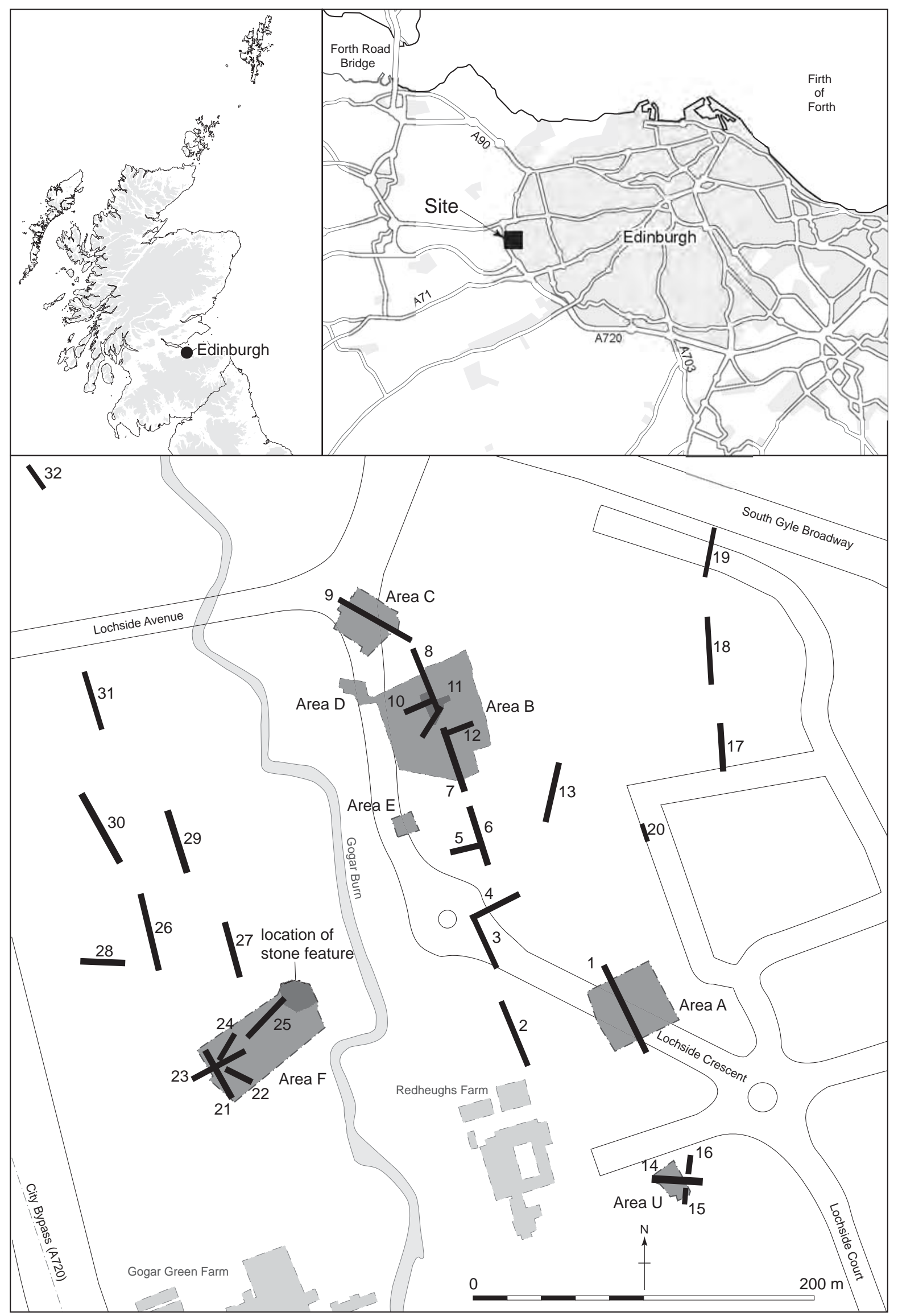

Illus 1 Site location, showing test trenches and excavation areas 


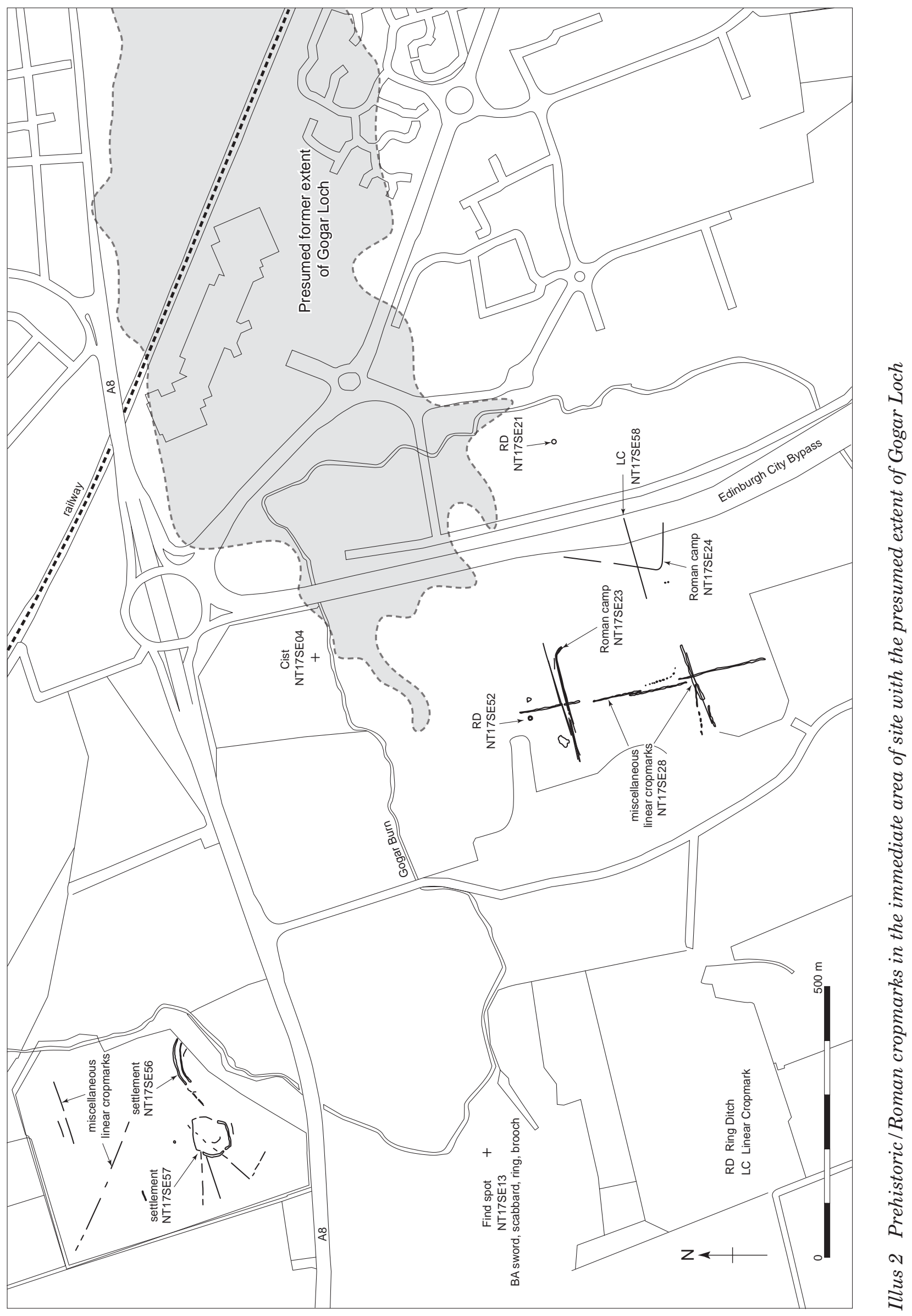




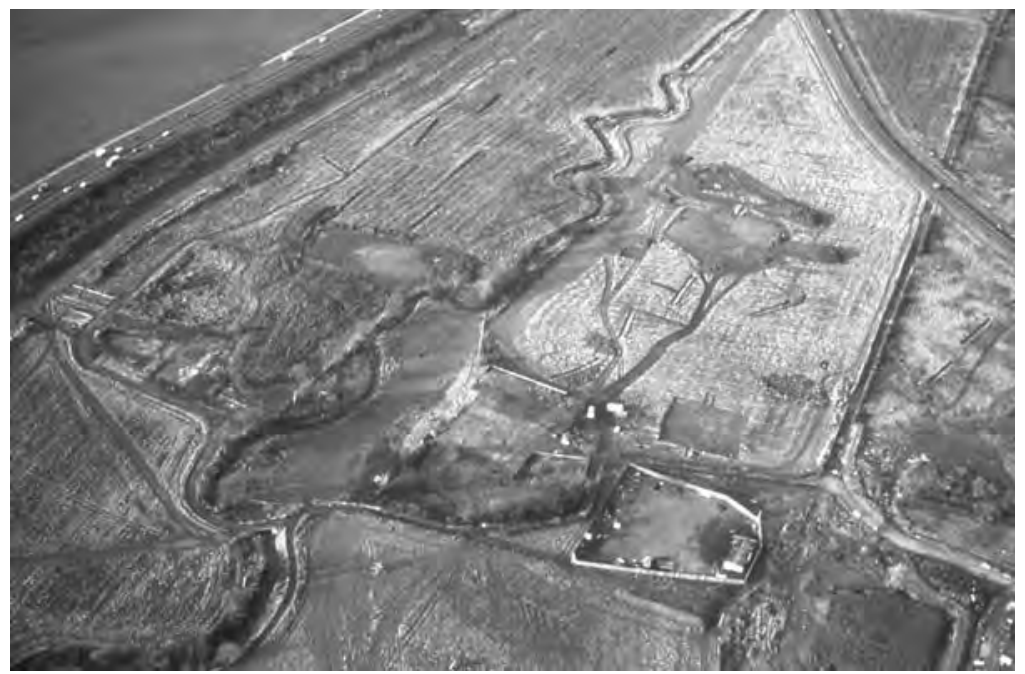

Illus 3 Aerial view of excavated areas (@RCAHMS) 


\section{$3 \quad$ Results}

\subsection{Evaluation}

The evaluation consisted of 32 machine-excavated trenches with a combined length of just over $1 \mathrm{~km}$ and a width of $2 \mathrm{~m}$ (illus 1 ), which represents an approximately $0.33 \%$ sample of the development area. The majority of the trench positions were selected on topographic grounds, while some were positioned to assess and intersect circular cropmarks located to the north of Gogar Green Farm, in particular NT17SE 21, and also to locate the eastern extent of Gogar Green Roman Temporary Camp. Features of probable prehistoric date were identified in Trenches 1, 7-12 and 21-25. Subsequent excavations were targeted on the areas surrounding these trenches. The findings from these trenches are discussed below within the areas that were opened around them. With the exception of isolated features of unknown/modern date, nothing of significance was found in the remaining trenches.

\subsection{Excavation}

\subsubsection{Area A}

Area A (illus 1) consisted of a roughly rectangular trench approximately $43 \mathrm{~m}$ long by $39 \mathrm{~m}$ wide $(1700 \mathrm{sq}$ $\mathrm{m})$, positioned to investigate features identified during the evaluation in Trench 1 . Interpretation of the features identified in Area A is difficult due to a lack of dating evidence or a coherent or understandable pattern. In particular, the protection provided by colluvial deposits elsewhere in the study area was

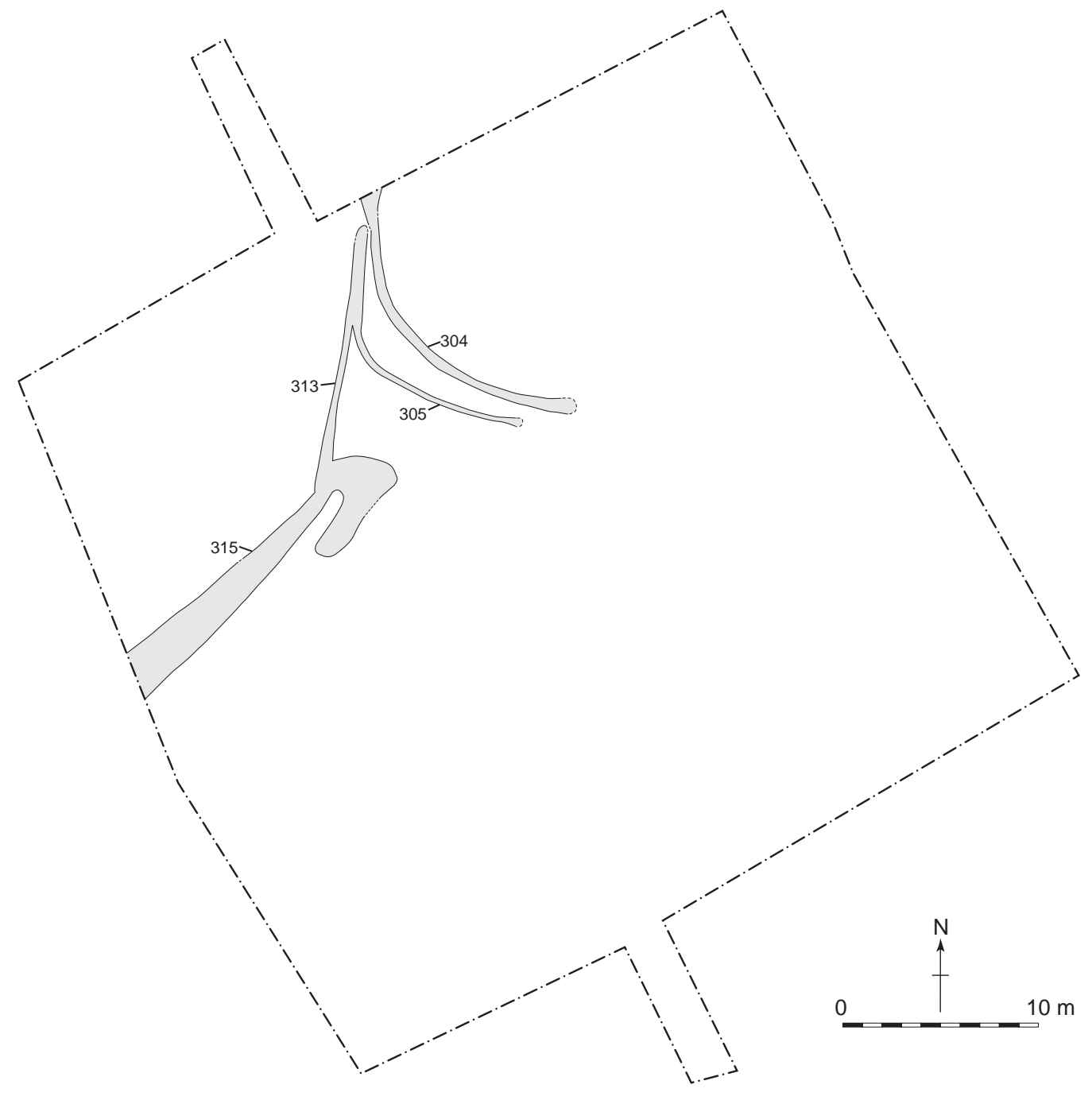

Illus 4 Plan of Area A, Phase I 
absent in Area A, resulting in substantial truncation of features and probably the complete destruction of all but the deepest features. Three stratigraphic phases of activity were identified although it is highly likely that these 'phases' were not separated by any substantial period of time and may represent successive elements of the same settlement.

\section{Phase I}

Stratigraphically, the earliest group of features identified at the site consisted of a group of linear and curvilinear features located in the north-west quadrant of the trench (illus 4).

A shallow ditch (context 313 ) approximately $13 \mathrm{~m}$ long and aligned from north-east to south-west was identified at the north end of the trench. This appeared to continue as the badly truncated base of a broad ditch (context 315) aligned south-west to north-east which ran for $16 \mathrm{~m}$ from the west edge of the trench. This was very shallow and irregular in profile (illus 5a). A group of irregular hollows lay in the area where these two features intersected and a stratigraphic relationship could not be determined.

Two roughly concentric curvilinear features (304 and
305) intersected with the north end of Ditch 313 . These curved off to the south-east where they terminated.

All of these features were heavily truncated, with only the bases surviving, and all had extremely similar fills, consisting of compact red-brown sandy silt, making it impossible to determine their stratigraphic relationships. The fills were homogenous and no indication of either natural silting or deliberate backfilling was noted. They were all cut by a third curvi linear feature (context 312), very close to the north trench edge, which has been allocated to Phase III.

The Phase I features did not survive sufficiently to allow a meaningful interpretation of their date or function. The most logical assumption would be that they represented some form of spatial division be it for domestic, agricultural or ritual purposes. The concentric ditches (310 and 309) are likely to represent two phases of the same boundary. Unfortunately, no chronological indicators were retrieved from these features.

\section{Phase II (illus 6)}

Four pits were identified at the centre of the excavation trench (Pits 317, 321, $325 \&$ 380). These

a
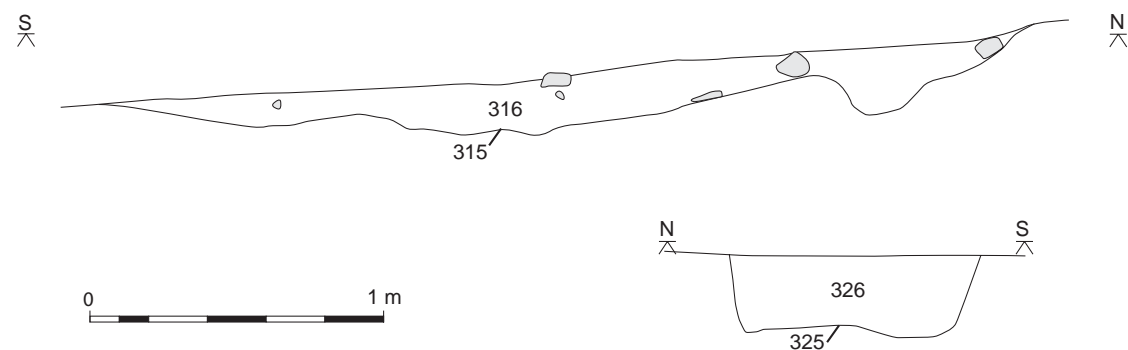

b
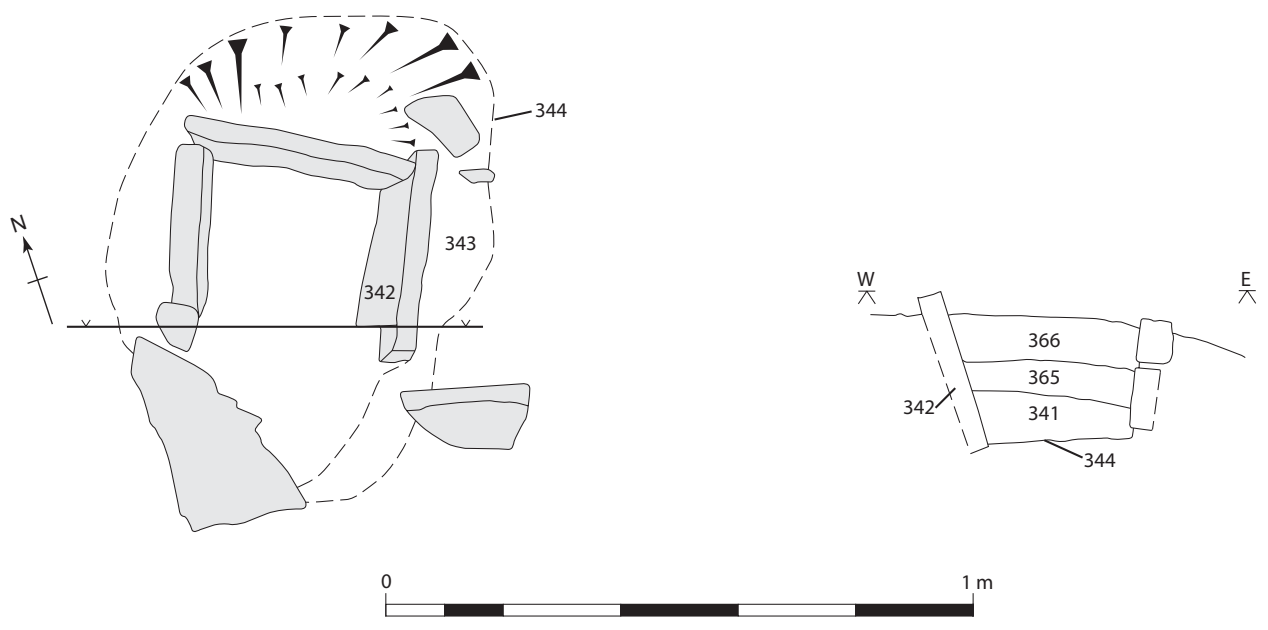

Illus 5 a sections of Features 315 and 325; $\boldsymbol{b}$ Plan and section of Feature 344 


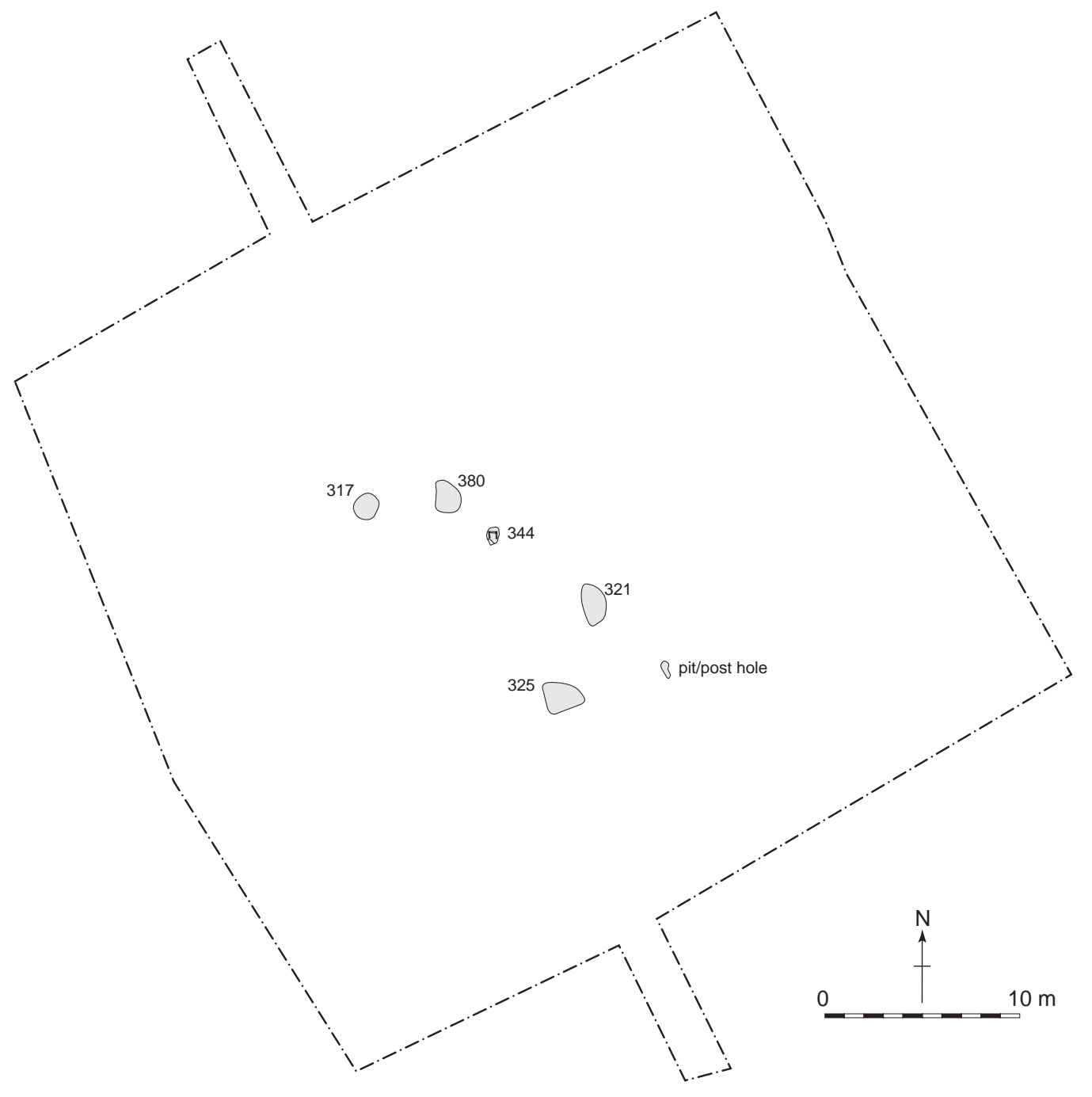

Illus 6 Plan of Area A, Phase II

were largely irregular in plan, with the exception of a roughly circular cut for Pit 317 , which formed the easternmost pit of this group. The fills of these features were very similar, consisting of either red-brown clay loam or red-brown silty loam with occasional cobbles or small angular pebbles.

Possibly associated with this group of pits was Feature 344, a stone-lined pit. A fragment of stone slab from the surface of the pit indicated that the feature was originally capped (illus $5 \mathrm{~b}$ ). The cut (context 344) was roughly rectangular in plan with slightly concave sides and a flat regular base. Within the cut, three upright slabs were set on the north, east and west sides to form a three-sided box (context 342 . This box was set in a matrix of dark red-brown silty loam (context 343). This stone-lined pit was the only feature from Phase II which provided some evidence for date or function on typological grounds. This had the appearance of a cist but no burial or grave goods were recovered from within it. It was also quite small (approximately $0.25 \mathrm{~m}$ by $0.4 \mathrm{~m}$ ). The lack of human remains is not, however, surprising as no bone was preserved in any context on the site due to the acidic nature of the receiving environment. It is possible that the cist was either constructed to hold the remains of a small infant or possibly held a cremation, though alternatively it may have simply served some form of storage function.

\section{Phase III}

The Phase I and II features were, in places, cut by a spread of negative features which have been grouped together as Phase III (illus 7). This was made up of two elements: a possible ring-ditch and an 'avenue' of post-holes.

At the north of the excavated area, a curvi linear ditch (context 312) was excavated which may represent part of a ring-ditch. Extrapolation of the curve of the feature would give a diameter of approximately $12 \mathrm{~m}$. The cut was regular with a concave base and the fill consisted of red-brown silty loam containing occasional small, angular and round stones. An 


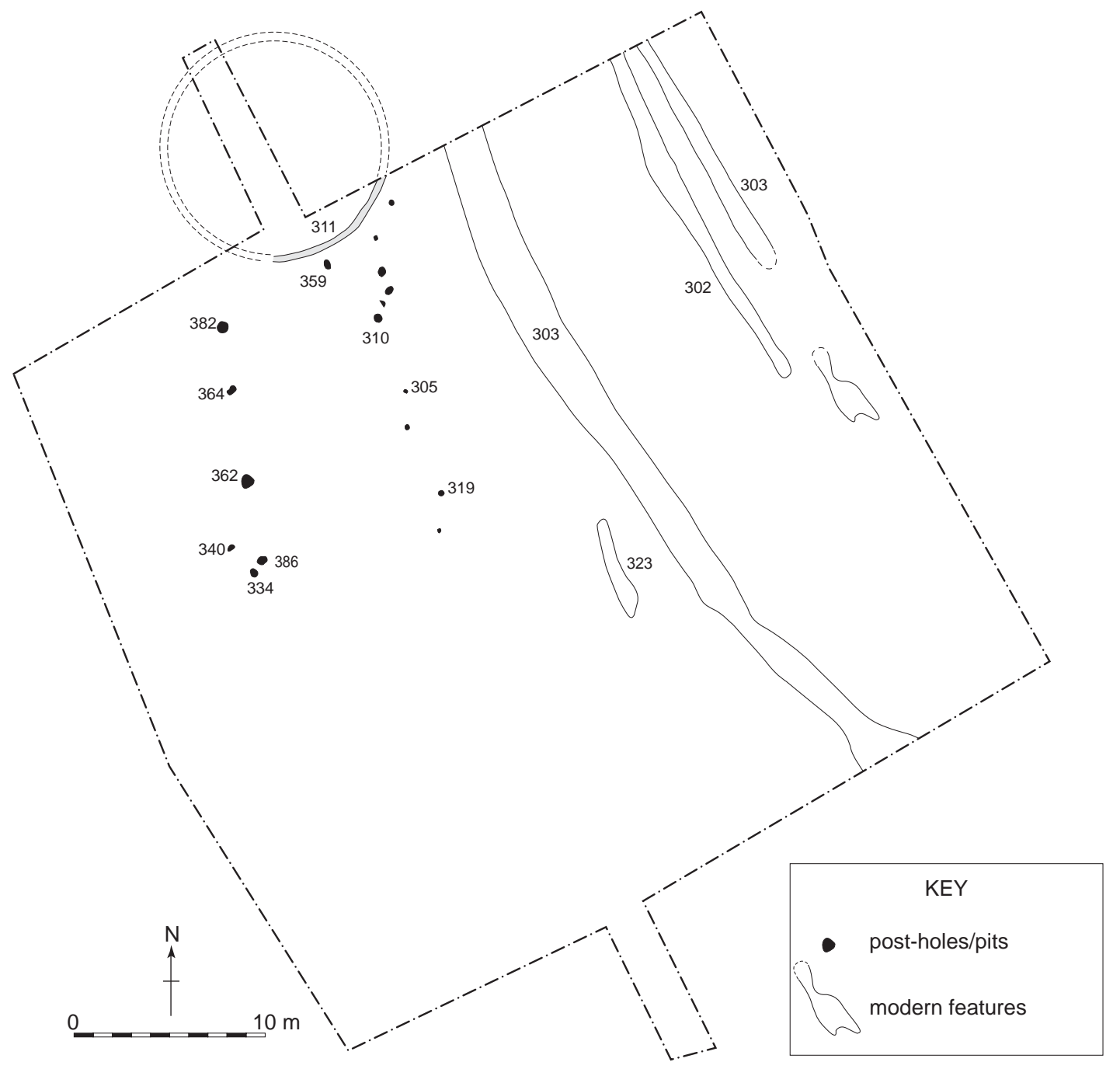

Illus 7 Plan of Area A, Phase III and modern features

extension trench was excavated in order to try and locate the northern extent of this feature; however, the results proved negative. The absence of any discernable return is most likely explained by truncation caused by medieval and later ploughing as the ground surface rose gently to the north. No artefacts were recovered from the fill of the ditch.

This ring-ditch may be the remains of a timber building, the dominant type of structure during the later prehistory of Britain (O'Sullivan 1998) and which is recorded, primarily from cropmarks, as occurring widely across the Lothians. Excavated examples - Melville Nurseries, Dalkeith (Raisen \& Rees 1995); Lamb's Nursery, Dalkeith (Cook 2000); Monktonhall, Inveresk (Hanson 2002), and Fishers Road, Port Seton (Haselgrove \& McCullagh 2000) - have demonstrated that this class of structure was widely used from the mid-second millennium $\mathrm{BC}$ to the mid-first millennium AD. The $12 \mathrm{~m}$ diameter of the Maybury Park ring-ditch fits well with these examples of excavated roundhouses and compares favourably with the Iron Age structures identified both from Monktonhall (Hanson 2002) and at Fishers Road, Port Seton (Haselgrove \& McCullagh 2000), where Structures 1, 2 and 3 at Fishers Road West all measured between $10 \mathrm{~m}$ and $12 \mathrm{~m}$ in diameter. Structure CS 1 at Fisher Road East was of similar dimensions.

An unusual variation from the normal plan of such buildings was evident on the south edge of the ring-ditch. Here two parallel rows of postholes, set $8.5 \mathrm{~m}$ apart, lead to/from the structure for $15 \mathrm{~m}$. The western alignment (Post-holes 382, $364,362,340,386 \& 334)$ ran in a straight line of four, at intervals of between $3.25 \mathrm{~m}$ and $5 \mathrm{~m}$, with two others (Post-holes 340 \& 334) lying close to Post-hole 386 at the southern end of the line. These three southern post-holes cut Ditch 315 . The eastern alignment of post-holes was composed of 10 smaller features. It was less regular than that to the west, and the intervals were between $0.7 \mathrm{~m}$ and $4 \mathrm{~m}$. Two of the post-holes cut Ditch 304 and one cut a large pit (379). Post-hole 359 was identified between the two lines, approximately $3 \mathrm{~m}$ west of the eastern alignment. 


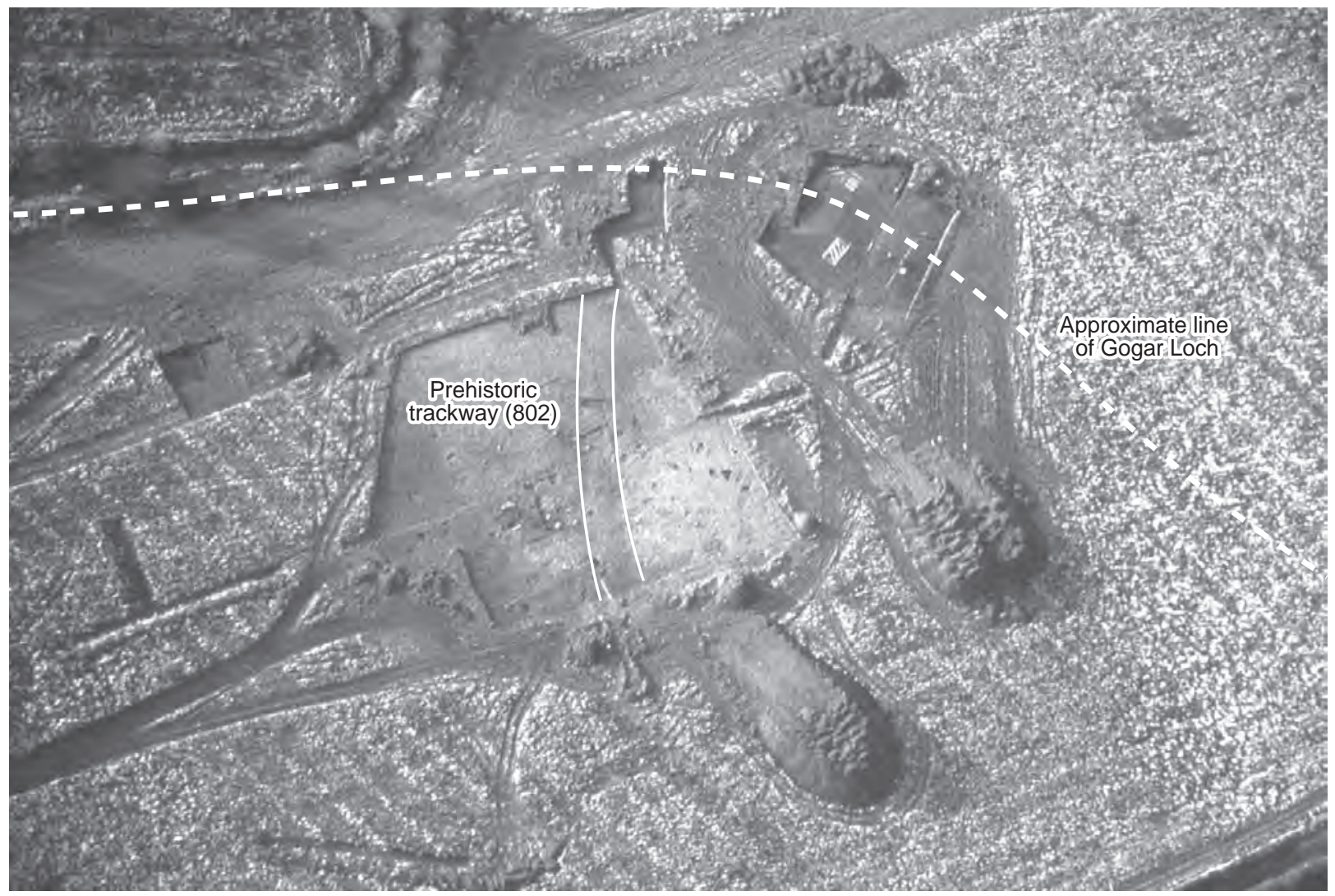

Illus 8 Aerial view of Areas B, C, D\& E, looking west (@ RCHAMS)

Elaborate entrances to roundhouses are not uncommon. House 1 at Lairg had three parallel lines of post-holes at the south-east which were interpreted as forming a long, timber-lined passage, possibly up to $6 \mathrm{~m}$ long (McCullough \& Tipping 1998, 37). A number of the early roundhouses at Catterick had extensive areas of paving/cobbling emanating from their entrances for a considerable distance, indicating the space outside the entrance was of considerable importance and heavily used (Moloney et al 2003, 13-21). At Maybury, there was no gap at the location where the 'avenue' met the ring-ditch and it may be that the arrangement of post-holes formed a small stock enclosure to the side of the building rather than an elaborate entrance or an external extension to the living space. At Catterick, a similar arrangement of post-holes (Structure 8010 ), $15 \mathrm{~m}$ long by $6 \mathrm{~m}$ wide, to the north-east of Structure 8004 was loosely phased with the Iron Age ring-ditches (Moloney et al 2003, 5 and fig 3) and interpreted as a rudimentary farm building such as a sheep/goat pen. A similar function could be envisaged for the Maybury post-holes.

\section{Phase IV: Post-medieval}

A number of parallel linear features running north to south through the eastern part of the site proved to be the result of medieval and later agricultural activity, ie drainage and rig and furrow (illus 7; contexts $302,303,323)$.

\subsubsection{Area B}

Area B was located in the saddle between two knolls and measured $4500 \mathrm{sq} \mathrm{m}$ (illus 1 ; illus 8). Once the site was stripped, several hundred features were identified; a large proportion of these proved to be either animal burrows or modern features, none of which are discussed here.

\section{Phase I: Neolithic/Bronze Age activity}

The earliest activity in Area B comprised a trackway and possible flimsy structure/shelter associated with a large pit. The trackway consisted of a large, broad linear feature (802) which ran from near the northwest corner of the excavation area diagonally to the south-east (illus 9; illus 10). This is likely to have been formed through erosion resulting from human and animal traffic. A length of over $56 \mathrm{~m}$ was contained within the trench. It averaged about $6 \mathrm{~m}$ wide and $0.2-0.4 \mathrm{~m}$ deep, with a flattish, very rough bottom. It crossed the slope at the south edge of the north knoll at an oblique angle. This trackway may well have extended further westwards as its western end, along with much of this section of the site, had been truncated by post-medieval ploughing. The fill of the trackway, which was sealed by a layer of colluvium, consisted of reddish-brown sandy silt (context 560) which contained a single fragment of struck chert.

In its eastern half, the southern edge of the trackway 


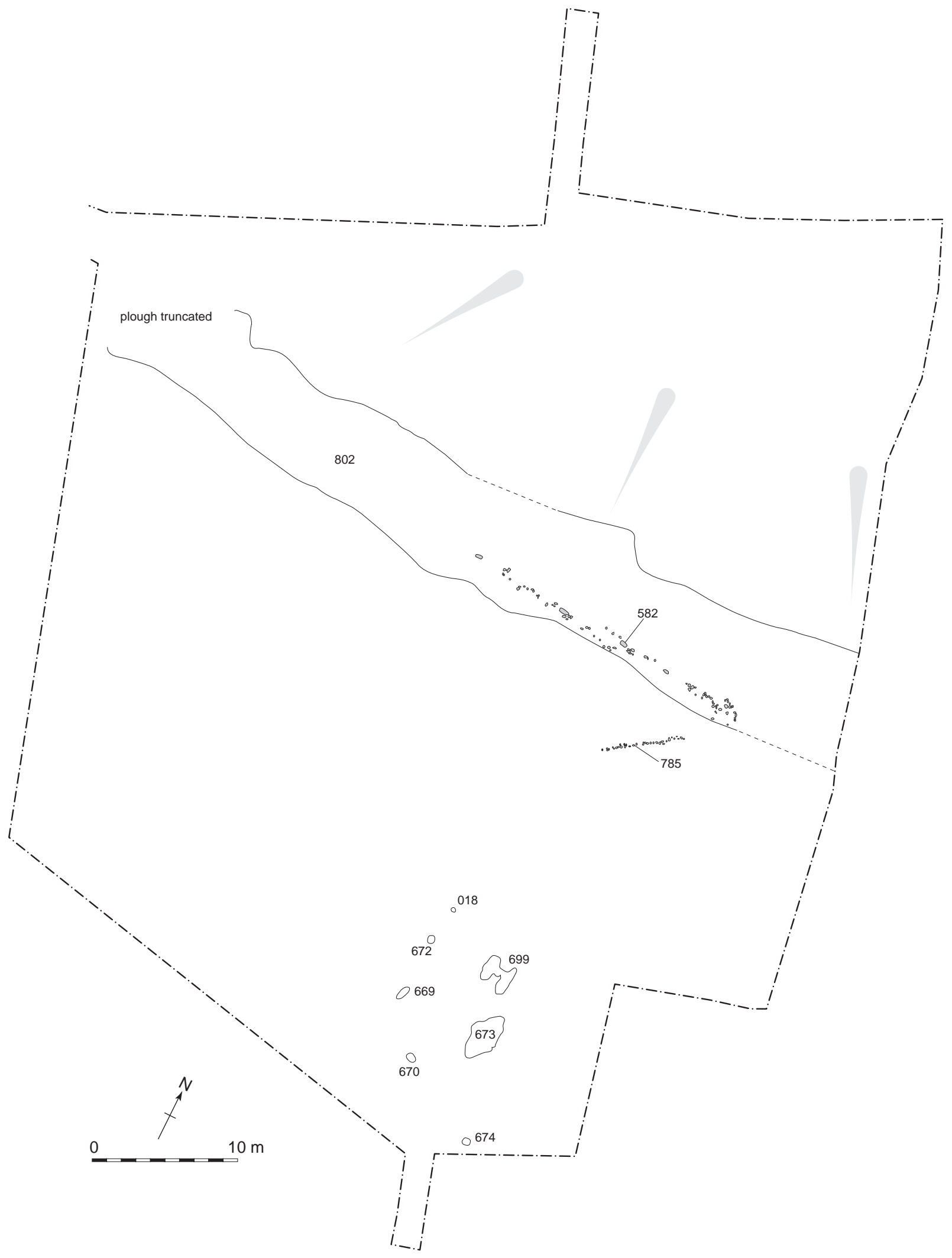

Illus 9 Plan of Area B, Phase I

was marked by a discontinuous line of large stones (context 582), some set on edge. In some places it was just possible to discern a cut and fill associated with these stones, but generally this was not possible. A further element of this feature was identified running on a north-east to south-west alignment to the south of the main line (context 785).

Dating of the trackway is dependent on stratigraphy. Fragments of probable Bronze Age pottery were found in a small pit which cut into the centre 


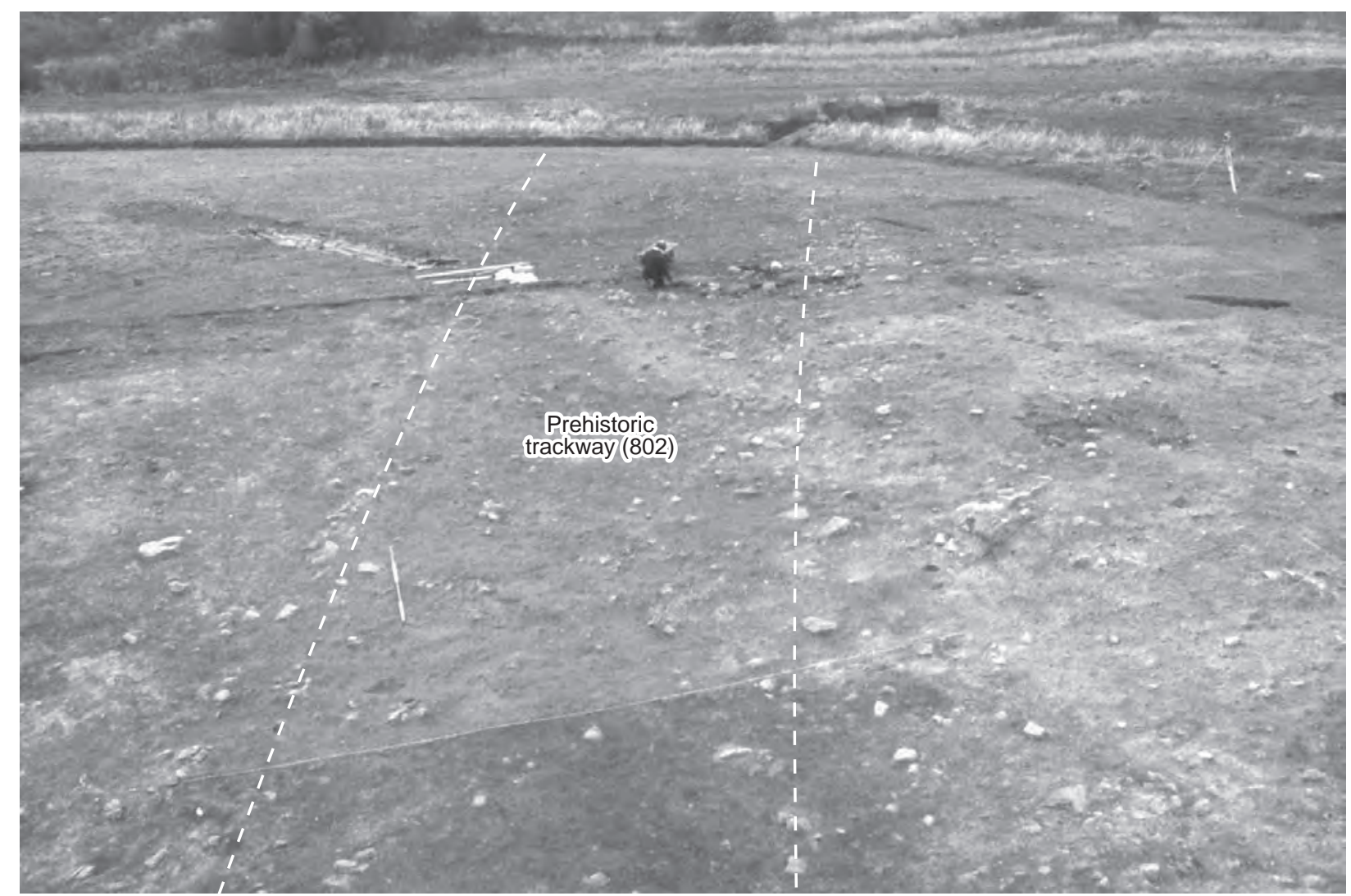

Illus 10 View of possible trackway (context 802)

Table 1 Radiocarbon dates

\begin{tabular}{lllll}
\hline Lab code & Area/Context & Sample material & Lab age BP $\boldsymbol{\delta}^{\mathbf{1 3}} \mathbf{C}(\mathbf{0} / \mathbf{0 0})$ & Calibrated (2-sigma) \\
\hline GU-11069 & B 552 & Hazel & $2830 \pm 50$ & $880-830 \mathrm{BC}$ \\
GU-11070 & B 636 & Alder & $3740 \pm 50$ & $2310-1950 \mathrm{BC}$ \\
GU-11071 & B 649 & Hazelnut & $4710 \pm 55$ & $3640-3360 \mathrm{BC}$ \\
GU-11072 & B 671 & Hazel & $4995 \pm 55$ & $3950-3660 \mathrm{BC}$ \\
GU-11073 & B 718 & Plum & $2730 \pm 45$ & $980-800 \mathrm{BC}$ \\
GU-11074 & F 1129 & Hazel & $2020 \pm 50$ & $170 \mathrm{BC}-\mathrm{AD} 80$ \\
\hline
\end{tabular}

of the trackway, and radiocarbon analysis of a sample from a small pit (712) which cut the edge of the trackway provided a date of 2310-1950 cal BC at 2-sigma (GU-11070; Table 1), again indicating a Neolithic or Early Bronze Age date for the abandonment of the feature.

Prehistoric trackways or droveways have been identified in numerous locations throughout Britain and Ireland and these are generally of the same form throughout prehistory. From the earliest known examples these have consisted of two parallel ditches which are believed to have had external banks surmounted by hedges. Animals were driven along between the ditches, sometimes causing a hollow to be eroded by the traffic. Such droveways were in existence from the Neolithic, as at the Ceide Fields, Co Mayo, Ireland, and continued in use up to the Late Iron Age and beyond, as with the extensive trackway system recorded in West Yorkshire in advance of the construction of the M1-A1 Link Road (Roberts et al 2001). The Maybury 'trackway' has no evidence for such defining ditches identified elsewhere. It is possible, however, that hedges grown each side of the hollow may have left no visible trace in the archaeological record (as demonstrated by Pryor 1998, 71). However, the stone linear feature (582) has been tentatively identified as remnants of a boundary; possibly packing stones for a fence.

Trackways are generally designed to manage the movement of animals. At Fengate, a sufficient area of a prehistoric landscape was excavated to postulate the function of such a trackway (Pryor 1998). Here it was shown that the trackway formed the main element of a field system that was laid out along the fen edge and at right angles to the wetlands. Animals stayed on the dry edge of the fen 


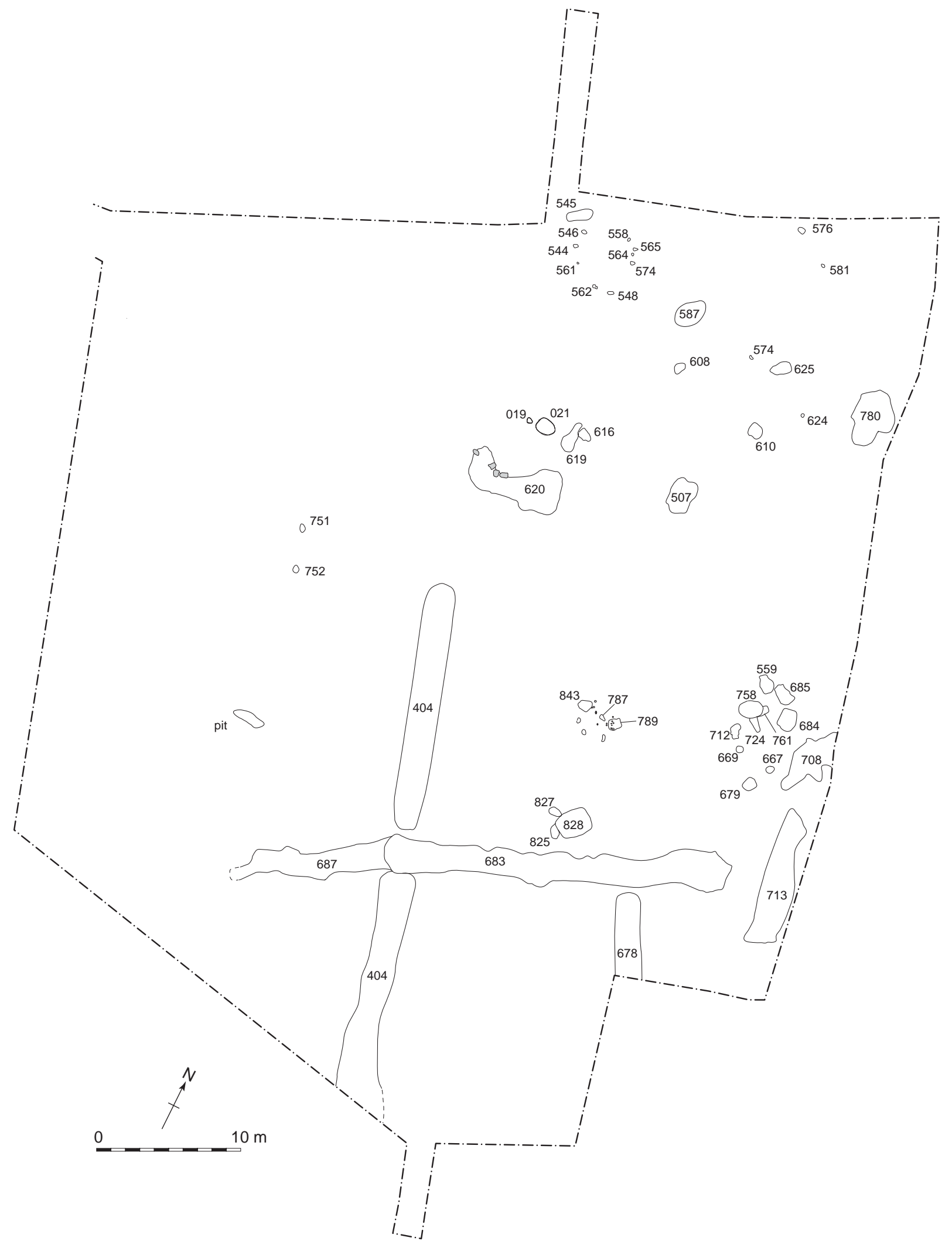

Illus 11 Plan of Area B, Phase II

during winter and were moved into the wetlands during the drier months of the summer. Assuming trackways were designed for 'structured mobility', it is difficult with the available evidence to determine the function of the Maybury 'trackway'. The prehis- toric topography would have consisted of higher and drier ground to the south of the site, with a broad, lower area of marshy ground running west/east along the northern edge (S Carter, pers comm) (illus 2). Using the Fengate model, it would be assumed 


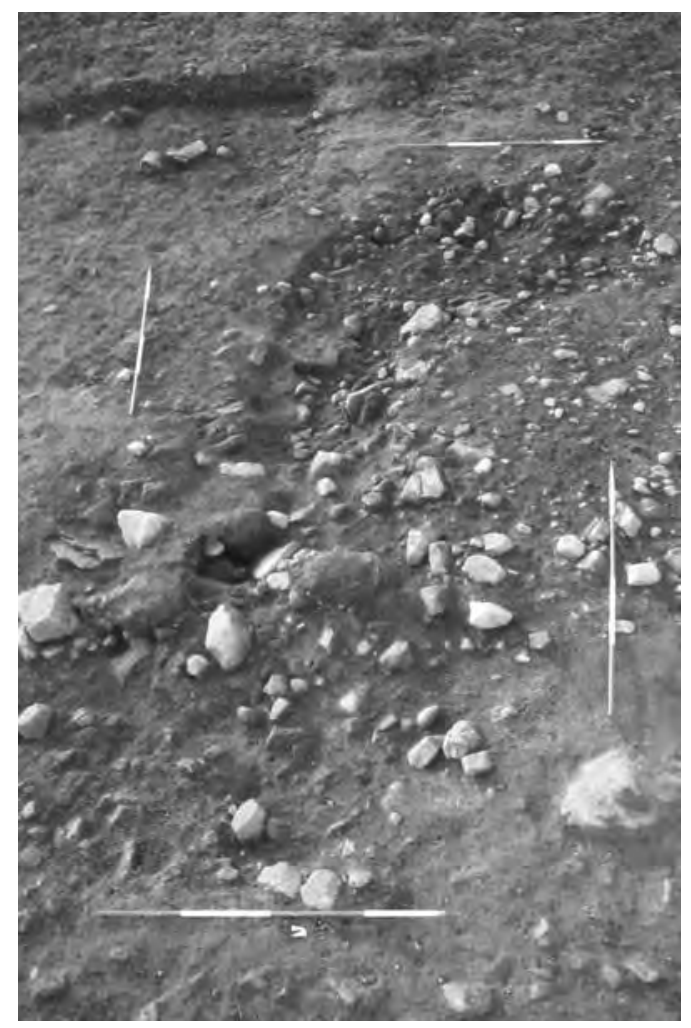

Illus 12 'Banjo-shaped' Feature 620

that the 'trackway' would have linked these two environments and not run parallel to them. It is possible, however, that the trackway was skirting around the knoll at this point, heading towards the Gogar Burn and a possible crossing point.

A slightly curving line of five widely spaced large post-holes or small pits $(018,669,670,672 \& 674)$ was located near the south edge of the excavated area (illus 9). These varied in depth between $0.16 \mathrm{~m}$ and $0.33 \mathrm{~m}$ and were irregular in plan and profile. The fills were consistently dark brown silty sand containing occasional rounded stones. A large, elongated oval pit (673) appeared to be partially enclosed by the five post-holes. On excavation, this feature proved to be very irregularly shaped. Its west side was very shallow, forming a 'step' down into the deeper east side. The north and south ends were both deeper than the central part. A bank or dump of stones had been placed on the base of the pit across the shallow central area, separating the north and south ends. The main fill of dark yellowish-brown silt (649) was uniform, and contained two sherds of prehistoric pottery interpreted as from a Carinated bowl (see Section 5.1). This type of pottery is not indicative of function and could have derived from a domestic, ritual or funerary context (A Sheridan, pers comm). A radiocarbon date of 3640-3360 cal BC at 2-sigma (GU-11071) was obtained from carbonized material retrieved from this deposit, which would confirm the Neolithic date attributed to the pottery. A very fine, dark, probably burnt lower fill (context 671) was recognized in the deep part of the south end of the pit only. A radiocarbon date of $3950-3660 \mathrm{cal}$ BC at

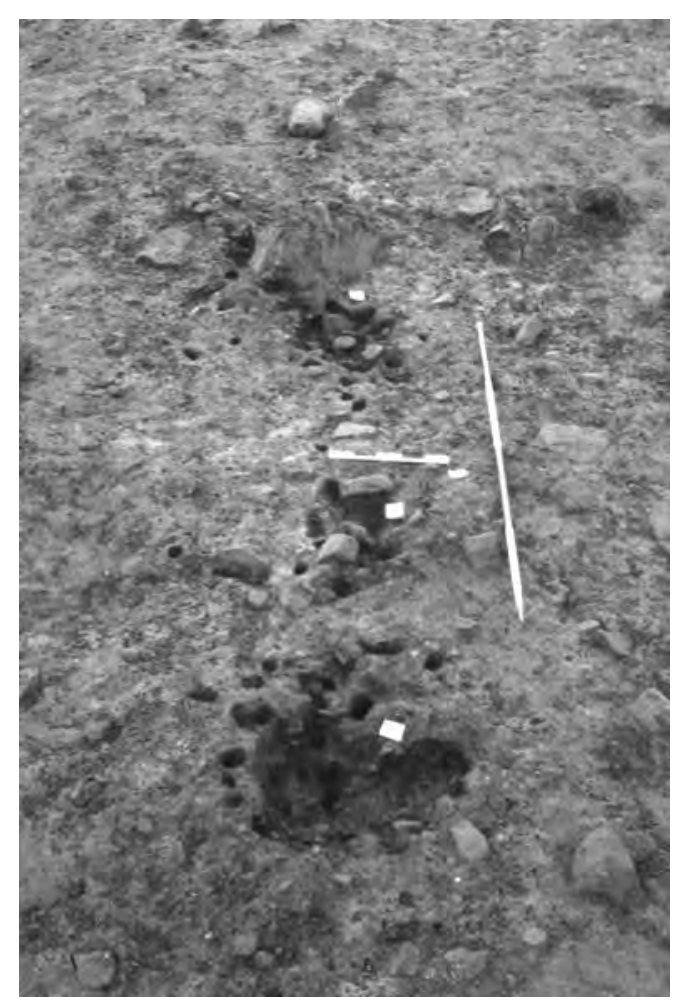

Illus 13 Hearths 789 and 843

2-sigma (GU-11072) was obtained from this deposit, again confirming the Neolithic date. Immediately north of Pit 673 was a shallow H-shaped feature (699) filled with burnt stone and clay that was orange from the effects of heat. The excavator considered it more likely that the deposit was dumped after burning rather than burnt in situ as the surrounding subsoil was not affected by heat.

It is assumed that the curving line of five pits/postholes were related to the central pit and the hollow filled with burnt material. The pit appears to have been deliberately shaped to form a stone-lined depression with a step down into it, presumably for ease of access. The primary fill exhibits evidence of burning and the adjacent hollow filled with heated stones and clay would also appear to indicate that fire was involved in the activity represented by the group. As the prevailing wind is from the west, it is possible that the post-holes held some form of wind-break to assist with the process which involved fire. This may represent a simple domestic shelter. The location of this group of features adjacent to the trackway may be significant and it is plausible that the two are related.

\section{Phase II: Later prehistoric features (illus 11)}

A series of four ditch segments appeared to form a small enclosure system to the south of the possible Phase I trackway. These did not align with the trackway although Ditch Segment 404 appeared to terminate at the southern side of Ditch 802, indicating it may have respected the line of the trackway. 
Alternatively, this may be a coincidence due to later truncation.

The longest of the ditch segments (404) ran for approximately $36.5 \mathrm{~m}$ to the south edge of the excavated area and was $2.75 \mathrm{~m}$ wide and $0.23 \mathrm{~m}$ deep at maximum. The feature was filled by a deposit of dark brown silty sand (403) with no inclusions. The other main ditch (contexts $683 \& 687$ ) in the complex ran from east to west for approximately $33 \mathrm{~m}$, and averaged about $1-1.5 \mathrm{~m}$ wide. The average surviving depth was about $0.15 \mathrm{~m}$. The fill of the feature consisted of dark red-brown sandy clay (661). Two similar ditches were identified aligned on the same grid pattern: Ditch 678 extended into the site from the south trench edge for $8 \mathrm{~m}$ terminating at Ditch 683 , and had a fill of dark brown sandy loam with occasional gravel inclusions (645); Ditch 713 was located in the south-east corner of the excavation. This consisted of a shallow cut $2.02 \mathrm{~m}$ wide and $0.29 \mathrm{~m}$ deep. A length of $8.1 \mathrm{~m}$ of the feature survived, although it may have been part of the same ditch as an irregular linear feature (708) located directly to the north and cutting the line of the trackway (802). None of these features contained any datable finds.

A scatter of features of Bronze Age and later date was located to the north of the enclosure system to which they may relate. The earliest of these is likely to date to the Early Bronze Age. This consisted of a large irregular pit (507) with gently sloping sides located at the top of the slope, beyond the northern edge of the colluvium. It contained an assemblage of prehistoric artefacts (SFs 28, 38 \& 45), including a smashed Beaker vessel (see illus $21 \&$ illus 22 in Section 5.1.1) and a flint scraper found immediately under the vessel. Several large lumps of charcoal were found adjacent to the vessel. Also present was a large, irregular stone block, with two faces shaped by pecking, one dished and the other saddle-shaped; both were pierced by pecked conical holes (see illus 18 in Section 4.2). The whole assemblage was found near one edge of the feature. The fill of the feature consisted of dark yellowish-brown clay silt (506). Although no bones were found within the pit, it is conceivable that the feature represents a burial pit. Bone preservation was extremely poor throughout all areas investigated due the acidic nature of the gravel subsoil. Sheridan (see Section 5.1) states that undecorated Beakers are relatively rare in funerary contexts. All things considered, it is probable that Pit 507 represents an isolated Beaker burial and that the majority of the other features in the area relate to the Later Bronze Age.

Immediately north of Ditch 683, a large pit (828) was identified measuring $1.9 \mathrm{~m}$ in diameter (north to south) and $0.45 \mathrm{~m}$ deep (illus 12). It had a clay fill (contexts 837,838 \& 839) and overhanging sides, and was cut by a shallow irregular feature (context 827) (possibly an angled post-hole) which contained several sherds of pottery of probable Late Bronze Age date (SFs 68, 78, 80 \& 81; see illus 25 in Section 5.1.1). Another small irregular feature (825) was cut by the pit.

North of Pit 828 were three small pits in a row, aligned north-west to south-east (Pits 787, 789 \&
843). Each had a very distinctive main fill of bright orange sand and gravel, in the surface of which was a hollow filled with a brown soil (illus 13). Each pit was surrounded by large numbers of stake-holes; many of these cut the orange primary fills, but were overlain by the brown soil upper fill. In the case of the largest pit (789), some of the stake-holes cutting the orange fill formed a very regular semi-circular pattern on the west side of the pit. The orange colour of the main fills, which was not paralleled in any other part of the site either in natural or archaeological deposits, is likely to be the result of heating or chemical processes. The most likely interpretation would be that it served as a hearth with an associated stake-built structure, possibly to assist with cooking.

A concentration of features lay near the east edge of the excavated area, some cutting the possible trackway. A small, shallow, sub-rectangular pit (559), which cut the possible trackway, contained a near-complete bucket-shaped vessel of probable Late Bronze Age date (SF 40; see illus 23 \& illus 24 in Section 5.1.1). This feature had a very indistinct fill, and had been particularly badly damaged by burrowing animals. It was associated with three larger pits with very distinct, dark reddish-brown fills containing charcoal flecks (contexts 758, 684 \& 685). Prehistoric pottery was recovered from the fill of Pit 758, which was oval in plan and measured $1.8 \mathrm{~m}$ by $1.27 \mathrm{~m}$ by $0.39 \mathrm{~m}$ deep. Radiocarbon dates of $1130-830$ and $980-800 \mathrm{cal} \mathrm{BC}$ at 2-sigma (GU-11069 and GU-11073, respectively) were produced from charcoal sampled from this feature. The fill consisted of reddish-brown sandy silty loam (context 552). This feature also cut the trackway, and had an apparent structure in its base, represented by a sub-oval arrangement of small stake-holes surrounding a small post-hole. Pit 685 was roughly rectangular and measured $1.56 \mathrm{~m}$ by $0.82 \mathrm{~m}$ and was $0.34 \mathrm{~m}$ deep. The fill (549) consisted of dark reddish-brown sandy loam. The final pit in the group (684) measured $1.53 \mathrm{~m}$ by $1.24 \mathrm{~m}$ in plan, was $0.14 \mathrm{~m}$ deep and was filled by a deposit of dark reddish-brown sandy loam (550). Pit 758 cut two smaller pits, one of which (Pit 761) contained the rubber from a saddle quern (SF 74) positioned together with two other stones as packing for a post.

This cluster of features may represent a domestic structure, although no discernible foundation could be identified. The presence of a hearth, pottery and a quern stone would be consistent with the contents of a domestic building. Pit 685 also contained the highest concentration of barley from the site as well as emmer wheat and oat-grass. Barley was also contained in other features from the group, although in lesser quantities. It can only be assumed that, if the group does represent a building, the structure had negligible or no foundations. It is assumed that the two small groups of features to the south-west (centred on Features 787 and 828) are representative of ancillary activities associated with this possible structure.

Immediately to the south of the pit group there was a pair of shallow hollows (669 and 712), interpreted as hearths. Both contained large quantities 

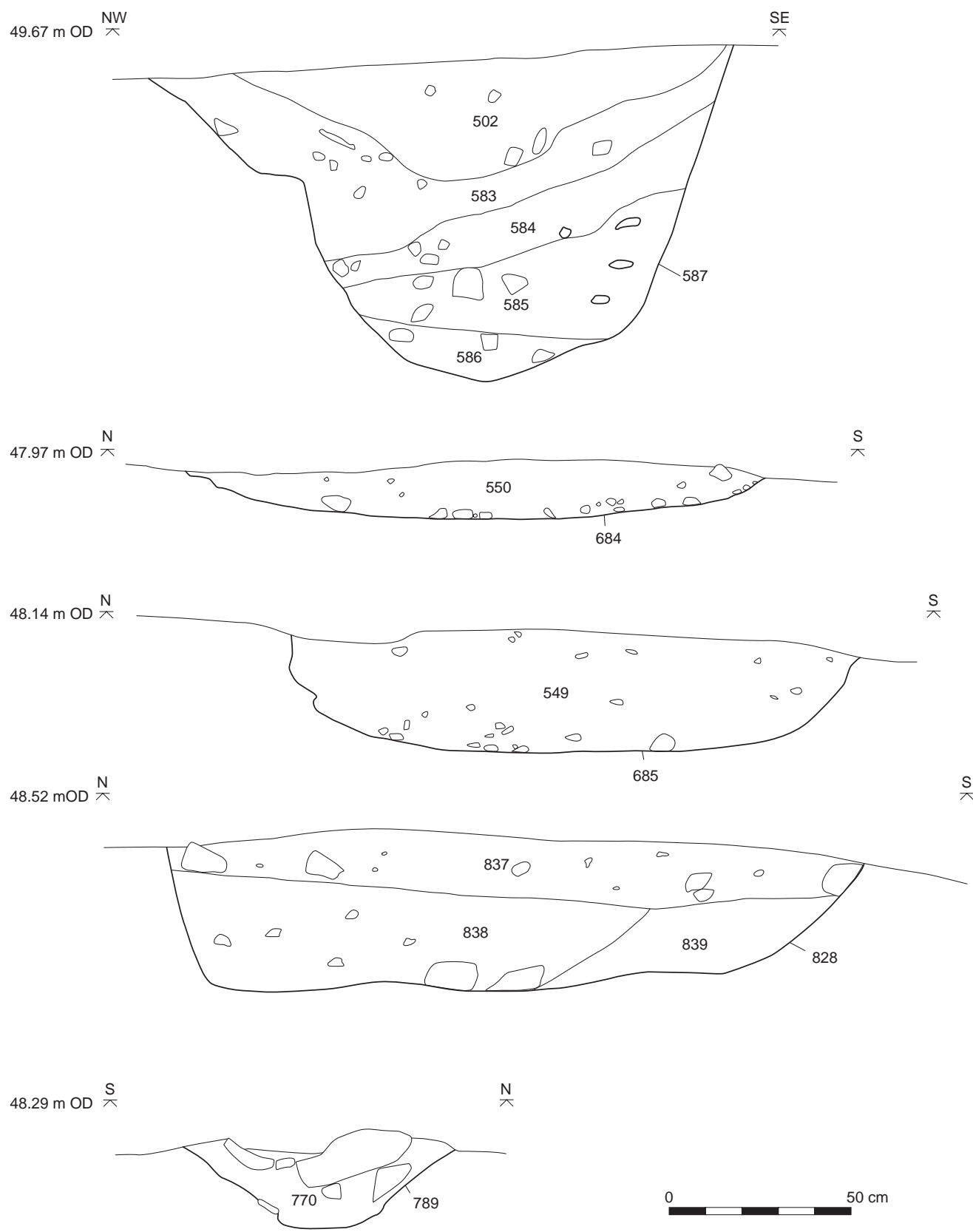

Illus 14 Selection of sections from Area B, Phase II

of very heavily burnt water-rolled pebbles, heated from one side. A very dark deposit, including crushed charcoal, lay at the centre of the reddish fill of each hollow. The fill of Hollow 669 was overlain by the spread fill of Hollow 712, which contained a sherd of undiagnostic prehistoric pottery. Two small postholes (667 \& 679), both different in character to each other, were adjacent to the hearths but contained no dating evidence. These features could also be associated with the tentative domestic structure immediately to the north and may relate to the heating of stones to add to a trough in order to boil water as would be expected with a burnt mound.

Positioned on the top edge of the slope, but further to the west, was a possible domestic structure (620).
It consisted of a broad, shallow sub-oval hollow cut into the slope, with a very irregular bottom and a maximum (surviving) depth of $0.3 \mathrm{~m}$ (illus 14). It became very shallow and indistinct on its southern (downhill) side. The western side extended into a narrower, passage-like feature which ran for approximately $3.9 \mathrm{~m}$ to the west before turning sharply to the north and ending at a rounded terminal. Overall, the feature was roughly banjo-shaped, and resembled some of the 'miniature souterrain' type features found at the Iron Age settlement of Dalladies (Watkins 1980, 122-64). A number of prehistoric potsherds of probable Iron Age date were found on the surface of the feature. One post-hole (019) and a pit (021) were found immediately to the 


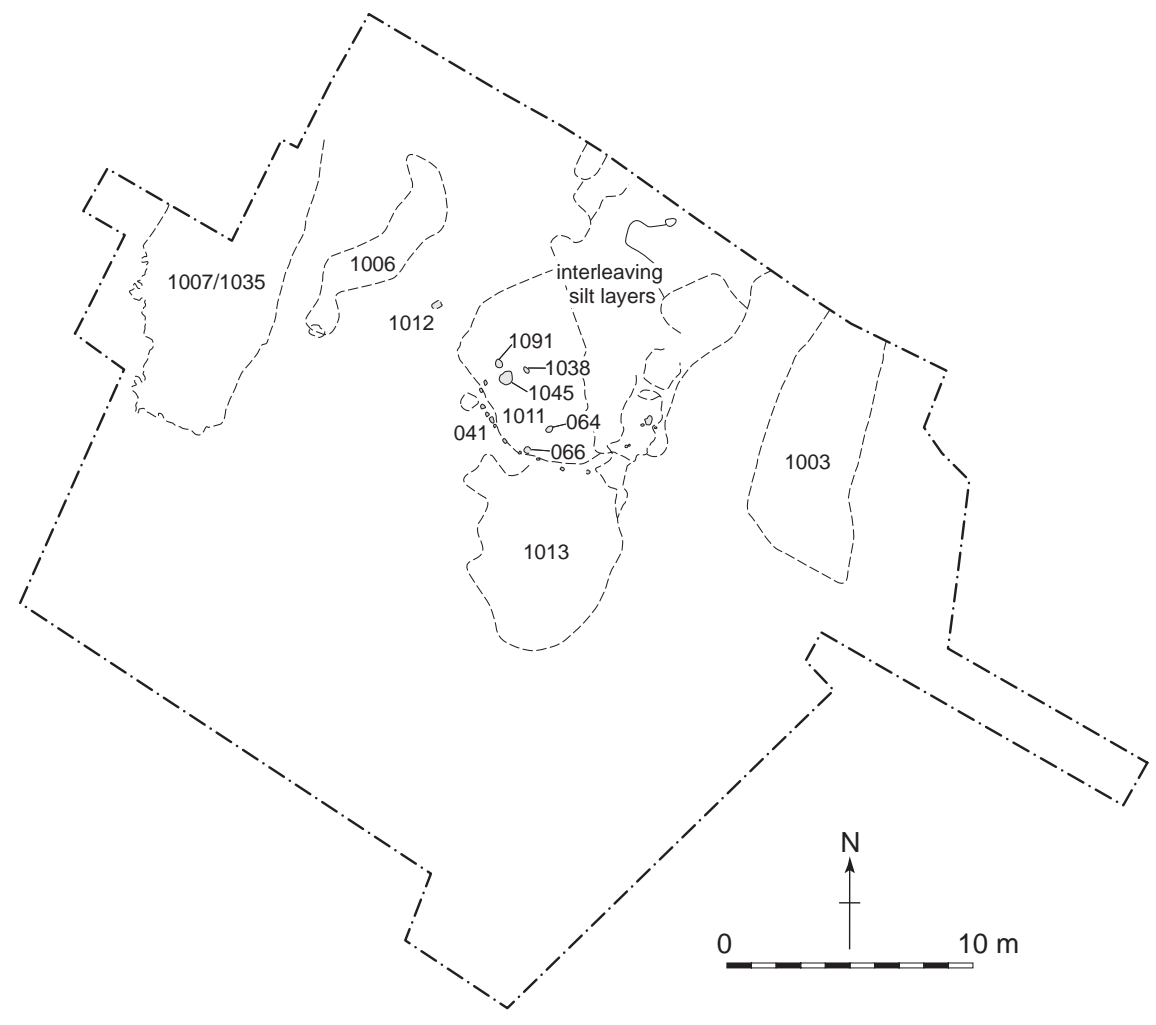

Illus 15 Plan of Area C

north during the evaluation, and the only piece of daub found in the project was located immediately adjacent to the feature.

The majority of features identified further north on the summit of the knoll proved to be of modern date. Three features or groups of features of possible prehistoric origin were, however, identified in this area. A small, shallow, flat-bottomed pit (610), sub-oval in plan, was lined with large stone blocks (611). The feature measured $1 \mathrm{~m}$ by $0.9 \mathrm{~m}$ in plan and was $0.19 \mathrm{~m}$ deep. The stone lining was sealed by a deposit of reddish-brown sandy silt (context 482). This feature was located at the southern edge of the summit area. Another small pit (608), located closer to the centre of the summit area, contained several contrasting fills (contexts 604, 605, $606 \& 607$ ) and had a large, flat stone pressed up against one side. At the south-west corner of the summit area, the bases of two very badly truncated inter-cutting, sub-rectangular features (616 \& 619) were identified. The only find recovered from any of these features was a single piece of burnt bone from context 592, the fill of context 616 .

At the extreme north of the excavation trench, a group of post/stake-holes $(544,546,548,558,562,564$, $565 \& 574)$ defined a roughly circular area approximately $4 \mathrm{~m}$ in diameter. Associated with this group of stake-holes was an oval-shaped pit (545) which measured $1.8 \mathrm{~m}$ by $0.79 \mathrm{~m}$ in plan and was $0.15 \mathrm{~m}$ deep. The fill consisted of dark reddish-brown clay sand (423). No evidence for a hearth or entrance was identified and no finds were recovered which would suggest domestic habitation. The apparent flimsy nature of the structure would suggest that it either represents a temporary shelter or possibly an animal pen.

Alarge area to the west of Ditch 404 and south of the possible trackway was largely sterile. One elongated, shallow pit and two post-holes (751 \& 752) were recognized, but could not be dated, and there were several modern post-holes filled with topsoil. Most of this area was not protected by colluvial deposits and any prehistoric features in this area would have been particularly vulnerable to destruction by ploughing.

The lack of stratigraphic relationships does not allow for chronological or spatial connections to be made between groups of features. The segmented enclosure may relate to some or all of the features located to the north of it. Both the radiocarbon dating programme and the pottery analysis suggest activity from the Early and Later Bronze Age and the Iron Age. The only conclusion that can be drawn from these chronological indicators is that the site shows evidence of human activity throughout the prehistoric period.

\subsubsection{Area C}

During the evaluation, three groups of features were identified in Trial Trench 9: a pair of gravel surfaces at the edge of the floodplain; a discontinuous arc of individual cobbles on the slope above and to the south of the surfaces, surrounding a very shallow deposit, formed apparently by the disturbance of the subsoil 
surface, and overlying a scatter of small stake-holes; a pair of post-holes lying in the area between the first two groups. All of these features were covered by a thick colluvial layer; towards the base of the slope this was mixed and interleaved with alluvial silt.

During the main excavation, an area of approximately $850 \mathrm{sq} \mathrm{m}$ was opened surrounding these groups of features (illus 1 ).

\section{The gravel surfaces}

The northern surface (contexts 1007/1035), lying slightly further out onto the alluvial plain, was stratigraphically later than the southern surface (1006), which lay directly at the base of the slope down to the edge of the plain (illus 15). The later, northern surface sat on the floodplain, at a stratigraphic interface between (underlying) alluvial silt mixed with coarser material washed down the slope and (overlying) pure alluvial silt. It proved to consist of several layers of small gravel, interleaved with layers of alluvial silt, implying a series of episodes of flooding followed by deposition. This resulted in a gradual process of extension to the north. The only artefactual association was a single flint flake found in a shallow hollow cutting the surface of the feature (interpreted as a pothole resulting from wear), but this cannot be seen as dating evidence.

The earlier surface (1006) was on the edge of the gravel slope, where it met the edge of the (overlying) alluvium mixed with coarser material. It was an irregular, discontinuous deposit of small to medium cobbles.

\section{Other features}

No continuation of the arc of cobbles (041) seen in the evaluation was recognized in the wider excavation area. This highly ephemeral feature, which had been interpreted as defining the edge of a possible circular structure, could easily have been destroyed or damaged either in antiquity or during machining and cleaning for the excavation. Furthermore, most of its area was overlain by a broad band of cobbles (1013) similar in size to those which formed the arc, making its recognition even harder. However, the deposit (1011) that had been defined by the arc of cobbles was recognized, together with several more associated stake-holes $(1091,1038,1045,064$ \& 066). These could not be shown to represent a clear structural pattern and the surrounding area was heavily disturbed by animal burrowing. It is very unlikely therefore that the possible circular structure identified during the evaluation was a real feature.

The overlying cobbles (1013) were spread over a band approximately $8 \mathrm{~m}$ wide, running across the slope. It could not be definitively proven to be of anthropogenic nature, although it could have been a spread bank. A hammerstone and some sherds of prehistoric pottery were recovered from it, but these cannot be treated as secure dating evidence and may derive from soil washed down the hill from the settlement identified in Area B.

Only one other feature, a single post-hole (1012), was recognized between the possible structure and the cobbled surfaces. This area had been extensively disturbed by animal burrows, which may have destroyed more features or affected their recognition.

\section{Discussion}

It would appear that the deposits initially interpreted as archaeological in Area $\mathrm{C}$ are the result of episodes of flooding on the edge of the loch, with finds washed in from either dumping or hill wash from the settlement in Area B. The presence of Neolithic artefacts may indicate that the focus of activity during this period was located between Areas B and C and was not excavated.

\subsubsection{Areas $D$ and $E$}

Two small areas of approximately 100sq $\mathrm{m}$ each were excavated at the lower west edge of the plateau (illus 1). No archaeological features were recognized, although it was shown that the gravel deposit forming the plateau had a very sharp edge where it had been cut away by an old course of the Gogar Burn.

\subsubsection{Area $F$}

This area of approximately $3000 \mathrm{sq} \mathrm{m}$ was excavated to investigate a cobbled surface recognized in Trial Trench 25, and in a further attempt to locate the cropmark ring-ditch which had not been located in Trial Trenches 21-24 (illus 1). As no sign of the ringditch was recognized and no other concentrations of features were identified, resources were concentrated on the investigation of the area around the cobbled surface. This transpired to form part of a large stone structure (illus 16).

\section{Topographic position of the structure}

The stone structure was located in a natural hollow on the eastern edge of a flat-topped plateau, where it was cut by the valley of the Gogar Burn. The subsoil in the area of the structure varied with gravel at the north-east corner, clays and silts beneath the area covered by the structure and to the north and south of it, and silt and sand to the west. In places, and particularly to the west, there were outcrops of small to medium angular stones and larger areas of continuous stone. The presence of the clays created an effective spring line, so that the lower (eastern) part of the hollow filled with water following rainfall and remained flooded for some time. 


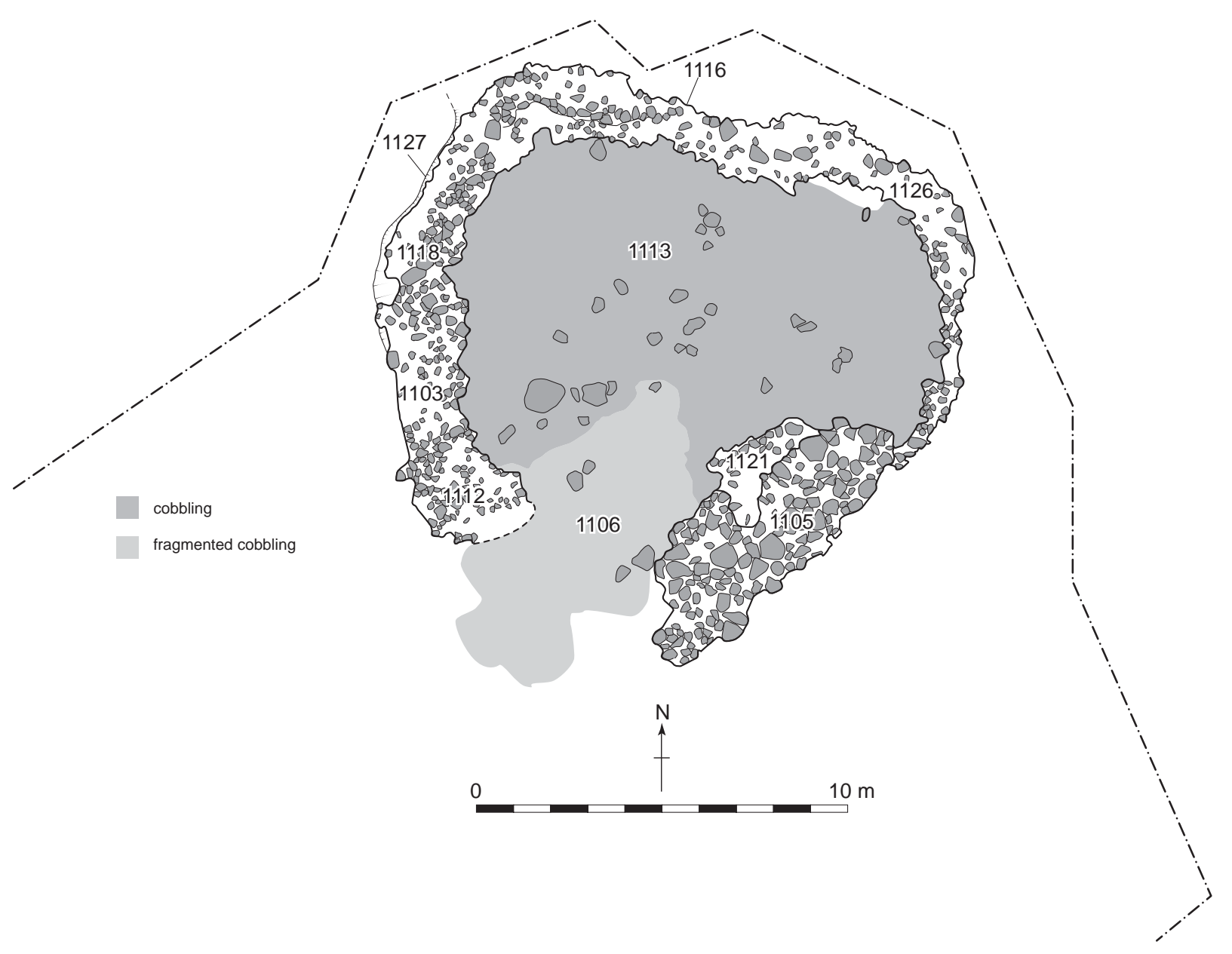

Illus 16 Plan of Area F

\section{Description of the structure}

The structure consisted of a series of continuous stone banks and surfaces forming an oval, bowl-shaped feature, measuring approximately $15 \mathrm{~m}$ north to south and $16.5 \mathrm{~m}$ east to west. It had been constructed in a natural hollow in the eastern edge of the plateau, with a steep scarp to the west, gentler slopes to north and south and level ground stretching away for $60 \mathrm{~m}$ to the east, up to the edge of the burn. The hollow had been enhanced before construction by clearing away all the topsoil and cutting into the subsoil at the north-west corner, to create a near-vertical face (context 1127). Further to the east, the cut was less steep and the face lower. The east-facing slope was unmodified, and lay at an angle of $45^{\circ}$.

The base of the hollow was concave, and was lowest near its east edge. During excavation, the easternmost $7-8 \mathrm{~m}$ filled with water during rainfall, and did not drain afterwards; bailing during periods of dry weather was required to empty it.

The inner metalled surface The primary construction event was the metalling of the hollow with hard-packed gravel (context 1113). The whole surface of the cut was covered, with the exception of the near-vertical slope at the north-west corner. The constituents of the metalling varied from small rounded gravel, which covered most of the hollow, to larger angular stones up to $0.30 \mathrm{~m}$ long. There had been no attempt to create a level surface prior to metalling, and projecting stones in the underlying subsoil were incorporated into the metalled surface; some of these projected as much as $0.40 \mathrm{~m}$ above the finished surface. In places, the surface had been eroded and damaged, possibly by use or by ploughing.

The stone banks The metalling of the hollow had been followed by the construction of upstanding stone features around the perimeter of the hollow, overlying the metalled surface. This appears to have followed the metalling almost immediately, as no sediment had accumulated and there was no apparent damage to the surface where it was covered by these features. The outer edges of these features coincided with the edge of the metalling, except on the south side, where the metalling extended $1 \mathrm{~m}$ further to the south, and on the near-vertical slope in the north-west corner, where the metalling was absent.

The stone features were varied in both the materials used and the method of construction. It is unclear whether these variations were determined by topographic or functional factors, or by both. 
The west side of the structure consisted of a simple revetment of the steep, east-facing natural slope of the edge of the subsoil forming the plateau. It consisted of a single layer of medium to large sub-rounded to angular stones (contexts 1103/1112), laid along the slope in a band approximately $10 \mathrm{~m}$ long from north to south and averaging $2.4 \mathrm{~m}$ wide. The highest point on the west edge of this band was approximately $1.4 \mathrm{~m}$ higher than the east edge. This feature could perhaps be seen as a coarser continuation of the metalling, rather than a separate feature. Like the metalling, it incorporated naturally outcropping stones, and it was badly damaged by ploughing along its upper west edge.

At its northern end, context 1103 merged into context 1118 without a discernible boundary, although the overall character of the two features was substantially different. Context 1118 was a stone bank built up against the near-vertical face of Cut 1127. It ran in a straight line for approximately $5 \mathrm{~m}$ from south-west to north-east, with a maximum height of $0.85 \mathrm{~m}$ at its south-west end, decreasing to the north-east, following the natural slope of the subsoil. It was built of small to medium stones and earth placed against the subsoil face and held in place by a revetment of larger stones placed in roughly horizontal courses at the lower level. The smaller stones and earth had been placed first, and the larger, revetting stones last.

At its north-east end, context 1118 turned to the south-east and continued in a straight line as a lower bank (context 1116) of similar construction. Unlike context 1118, however, this feature stood slightly above the level of the subsoil to the north. Its maximum height was $0.50 \mathrm{~m}$, at its junction with context 1118, and it became slighter towards the south-east end.

The eastern side of the complex was defined by a slight stone bank (context 1126) running in an arc from the south-east end of context 1116 around to the south-east corner of the structure. This feature ran along relatively level ground, proud of the subsoil surface and immediately beneath modern ground level. Consequently, it had been badly plough-damaged and spread; in some places only patches of the bank survived, and its average height was around $0.2 \mathrm{~m}$. At its southern end it was only $0.4 \mathrm{~m}$ wide.

The stone platform The south end of Bank 1126 joined onto the east end of a platform $8.5 \mathrm{~m}$ long built mainly of large, flat-topped stones (context 1105), which formed the south side of the complex. The south side of this platform had a straight edge, while its northern edge was much more irregular.

A line of medium to large stones (context 1121) ran from east to west, oblique to the north face of the platform. The west end of this terminated in an irregular patch of cobbles, which appeared to return to fill a hollow in the face of context 1105. A similar patch of cobbles filled the gap between the east end of contexts 1121 and 1105. This feature appeared to form a secondary extension or modification to the main part of the platform.

Two large stone artefacts were found within the banks and platform. A large hexagonal stone $0.34 \mathrm{~m}$ in diameter (SF 99; see illus 19 in Section 4.2) had two flat faces, each with a shallow central depression. This object had been built into the platform (1105). SF 100 (see illus 20 in Section 4.2), a large polygonal stone with a deep conical bowl and two smaller flanking holes in its flat upper surface, was found upside down within context 1103.

The ramp The south-west corner of the structure was occupied by a long, shallow ramp passing through a gap approximately $3 \mathrm{~m}$ wide, between the west end of the platform and context 1112 . The ramp ran north-eastwards into the interior of the hollow, and the metalling of its surface (1106) had a high proportion of larger, rough stone blocks and only a few areas of small pebbles.

The fills of the hollow There were two different primary fills in the hollow. A small area of dark green-brown silty loam (1129, not illustrated) had accumulated within the north-east corner of the base of the feature, overlying the base of the eastern stone bank (1126). This deposit contained an inclusion of crunchy black nodules, some of which were shattered. Charcoal was also recovered and provided a date of $2020 \pm 50(70 \mathrm{BC})$. In the remainder of the hollow, the primary fill was a thin, distinctive layer of pale silvery sandy silt (1130, not illustrated), which covered the whole of the lower part of the metalled surface and in places lapped over the edge of the stone banks. A single sherd of prehistoric pottery was recovered from this deposit (SF 97). This was overlain in the southern half of the hollow by a very dark greyish brown silty loam (context 1102, not illustrated) up to $0.2 \mathrm{~m}$ thick, containing two sherds of prehistoric pottery (SFs $88 \& 91$; see illus 27 in Section 5.1.3) and a small fragment of burnt bone (SF 96).

The whole complex as described above was covered by a deep accumulation of colluvial deposits. The lower element of this (context 1120) was a very dark grey clay loam with reddish mottling towards the top of the deposit. This graded upwards into a dark reddish -brown sandy silty loam (1101), which became much sandier closer to the modern ground surface. These colluvial deposits filled the entire hollow, covering the stone structures, and directly underlay the modern ploughsoil.

The upper part of the colluvium was partly removed by machine, leaving the lower $0.25 \mathrm{~m}$ of context 1101 and the whole of context 1120 to be removed by hand. This hand excavation produced two sherds of Iron Age pottery (SFs $87 \&$ 89; see illus 27 in Section 5.1.3) from context 1101 and a single sherd from context 1120.

The cairn A small cairn (1117, not illustrated) was encountered within the thickness of the upper 
colluvial deposit (1101). At the core of this cairn was a single massive boulder, $3 \mathrm{~m}$ long and oval in plan, with a curved upper surface and flat base. Around it had been placed a quantity of stones of the same type found in the stone banks. This cairn most likely relates to medieval/post-medieval field clearance of stones brought up by the plough from the underlying structure.

\section{Discussion}

The Maybury structure is very unusual and comparison with similar sites is difficult. It does not compare well with scooped cobble structures such as those excavated at St Germains (Alexander \& Watkins 1998) and Port Seton (Haselgrove \& McCullagh 2000) and it is difficult to see how the structure could have been roofed. The nearest comparable structures have been excavated at Easter Kinnear in north-east Fife by Stephen Driscoll (Driscoll 1997). Morphologically, one of these sites, excavated at Hawkhill, was similar to the Maybury example, with a stone-lined circular scoop and a ramped entrance from the south. The walls were constructed of rough boulders and the floor was consistently rough. The main contrast was that the structure at Easter Hawkshill was much smaller, measuring approximately $9 \mathrm{~m}$ by $8 \mathrm{~m}$, and had been deliberately backfilled. Other scooped stone-lined buildings were also identified at Easter Kinnear but none of the others compared so strikingly with the Maybury example. Interpretation was difficult at the Easter Kinnear sites as little evidence for function was retrieved. However, as the floors were roughly finished and there was no evidence for a hearth, a storage function was assigned to these. It was also suggested that they functioned as cellars for timber buildings. Chronologically, it is believed that the group of Easter Kinnear structures formed a 'hamlet' that was occupied for several centuries, possibly up to the medieval period. An attempt was made to identify further examples of these monuments from cropmark evidence in Fife (Fletcher 1993). Nine comparable sites were identified at South Friarton (NO42 NW68), Burnside (NO42 NE45), West Third (NO41 NE17), Newbridge of Ceres (NO41 SW17), Monimail (NO31 SW54), Esky Loch (NO42 NW56), Western Friarton (NO 42 NW64), Kirktonbarns (NO42 NW00) and Forgan (NO42 NW46). The largest group of scooped structures was identified at South Friarton, where 18 were noted, indicating a substantial or long-lived settlement. It has been tentatively suggested that these settlements are the precursor to the fermtoun.

No evidence was recovered for any superstructure at Maybury and interpretation of the original form and function of the structure is difficult. If the structure served as a cellar for a large circular timber structure, massive timbers would have been required to found such a building and these would surely have left a mark on the archaeological record. Again no evidence was identified for a hearth or for the general detritus that would be expected from domestic habitation. Therefore it seems unlikely that the site served a domestic function. This would leave either an industrial or ritual function, neither of which can be proved nor disproved with the available evidence. The location of the site next to the stream and that fact that it may have had standing water in it may point to an industrial function.

Dating for the Maybury example was restricted to a single radiocarbon date from the primary fill of the interior of the structure, which places the site in the Iron Age [170 BC (95.4\%) $80 \mathrm{AD}] 170 \mathrm{cal}$ BC to 80 cal $\mathrm{AD}$ at 2-sigma (GU-1174). A fragment of possible Dark-age pottery (see illus 21 in Section 5.1.1) was recovered from the topsoil in this area. However, as the fragment did not come from a secure archaeological context, it could not be related to the excavated features.

\subsubsection{Area $U$}

During the evaluation, a number of agricultural features likely to be of medieval or later date had been identified in Trial Trench 14. Several of these had overlain a stone-filled linear feature aligned north-east to south-west, which was seen as a possible structure. An irregular excavation area of approximately $280 \mathrm{sq} \mathrm{m}$ was opened and this feature was traced to both ends of the excavated area. It now seems unlikely to be structural, and is more likely to be a drain. Post-medieval green-glazed pottery was found in its fill. No other significant features were recognized. 


\section{Lithic Artefacts by Alan Saville}

\subsection{Struck lithic artefacts}

A small collection of 17 artefacts was recovered from a variety of contexts. Few, if any, of the artefacts are likely to be contemporary with these contexts, in which they are probably residual. Table 2 gives the typology and raw material of the struck artefacts and Table 3 summarizes their contexts.

None of the artefact types is clearly diagnostic of period, but a very wide chronological range is almost certainly represented. There are two unretouched bladelets, one of grey-green chert (SF 6, topsoil), the other of flint (SF 83, Area C, context 1013), which could both be of Mesolithic date, while the edge-trimmed flake (SF 44, Area B, context 543 ) is an incomplete blade perhaps more likely to be Neolithic. One of the miscellaneous retouched pieces (SF 45, Area B, context 589) is a fresh flint flake with denticulate scraper-like retouch at the distal end and could be of Middle Bronze Age date. Another of the (?flint) unretouched flakes (SF 10, context 046) could possibly be Mesolithic, as could the core rejuvenation flake (SF 86, Area C, context 1013) from the platform edge of a flint bladelet core. While none of these attributions is certain, it can at least be concluded that this is not a homogeneous assemblage.

The raw material, both numerically and by weight, is predominantly flint of mixed colour and type, with grey-green chert the only other significant material exploited. Two pieces are so heavily burnt that it is difficult to say if they are of flint or chert, and a further two unretouched flint flakes and one flint miscellaneous retouched piece have been burnt.

That some actual knapping was taking place in the vicinity is attested by the fragmentary core

Table 2 Typology and raw material of the struck lithic artefacts

\begin{tabular}{lccccccc}
\hline & $\begin{array}{c}\text { Grey-green } \\
\text { chert }\end{array}$ & $\begin{array}{c}\text { Purple } \\
\text { chert }\end{array}$ & Flint & $\begin{array}{c}\text { Flint or chert, } \\
\text { burnt }\end{array}$ & Quartz & $\begin{array}{c}\text { Total } \\
\text { nos }\end{array}$ & $\begin{array}{c}\text { Weight in } \\
\text { grams }\end{array}$ \\
\hline Unretouched flakes & 4 & 1 & 4 & 1 & 1 & 11 & 20.3 \\
Core fragment & - & - & - & 1 & - & 1 & 1.6 \\
Edge-trimmed flake & - & - & 1 & - & - & 1 & 1.9 \\
Miscellaneous retouched pieces & 1 & - & 3 & - & - & 4 & 20.1 \\
Total numbers & 5 & 1 & 8 & 2 & 1 & 17 & \\
Weight in grams & 11.7 & 1.7 & 26.5 & 3.1 & 0.9 & & 43.9 \\
\hline
\end{tabular}

Table 3 Struck lithic artefacts by context

\begin{tabular}{lccccc}
\hline Context & Unret. flakes & Core fragment & Edge-trim flake & Misc. retouched & Total \\
\hline Topsoil & 3 & - & - & - & - \\
25 & 1 & - & - & - & 3 \\
37 & 1 & - & - & - & 1 \\
46 & 1 & - & - & - & 1 \\
50 & 1 & - & - & 1 & 1 \\
103 & - & - & - & - & 1 \\
104 & - & 1 & - & - & 1 \\
520 & 1 & - & 1 & - & 1 \\
543 & - & - & - & - & 1 \\
560 & 1 & - & - & 1 & 1 \\
589 & - & - & - & 1 & 1 \\
1001 & - & - & - & - & 1 \\
1007 & - & - & - & 4 & 2 \\
1013 & 2 & - & 1 & 1 \\
Total & 11 & 1 & & & 1 \\
\hline
\end{tabular}



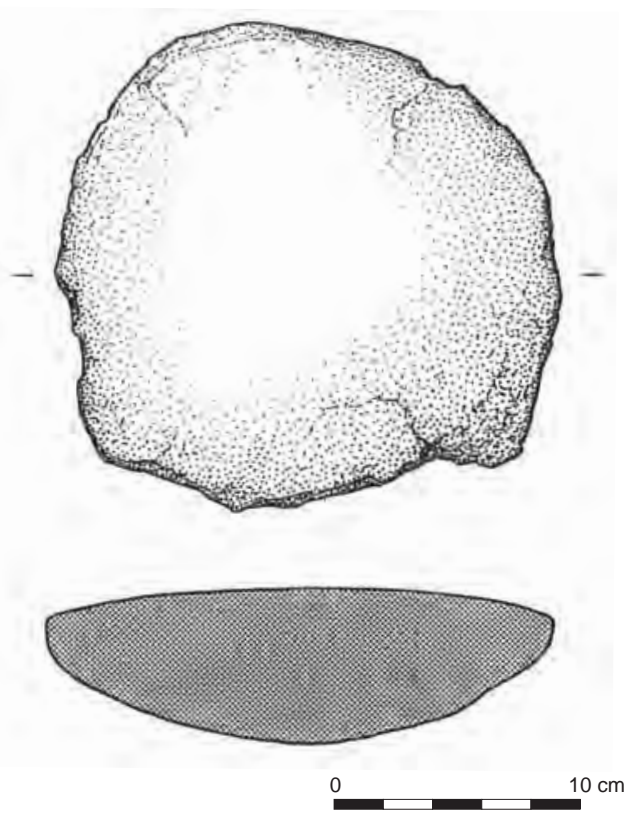

Illus 17 Quernstone (SF 79)

(SF 19, context 104) and the presence of two core platform rejuvenation flakes, one of flint (SF 86, Area C, context 1013), the other of grey-green chert (SF 25, topsoil), among the unretouched flakes. However, the very low numbers of struck artefacts as a whole indicate no intensity to this knapping, and no significant conclusions can be reached on the basis of their presence.

\subsection{Coarse stone artefacts}

Four modified coarse stone items were recovered. These are described separately and each one is illustrated.

Quernstone (SF 79, Area B, context 760, illus 17). This small quernstone of diorite, green-greybuff in colour, is broken at one end and has several cracks, perhaps the result of heat damage. It has an oval planform and a basically semi-circular crosssection, though the upper surface is slightly convex. The quernstone has been shaped by pecking and the upper surface is worn smooth by use. Length $200 \mathrm{~mm}$; maximum width $205 \mathrm{~mm}$; thickness 50 $80 \mathrm{~mm}$. Weight $3.9 \mathrm{~kg}$.

As Ballin Smith has discussed (Ballin Smith 1994, 204), small plano-convex quernstones of this type are somewhat problematic in terms of function. They are too large to be a hand-held upper stone or rubber, but as a lower stone it is difficult to envisage the purpose of the abrasive use which would produce a convex surface.

Stone block with two opposed hollows (SF 38, Area B, context 506, illus 18). An irregular block of sandstone (grey-buff-brown colour) with diametrically opposed hollows or cups pecked into the upper and lower flattish surfaces. The hollows are conical in profile, one $60 \mathrm{~mm}$ diameter and $35 \mathrm{~mm}$ deep, the other $59 \mathrm{~mm}$ in diameter and $30 \mathrm{~mm}$ deep. The block is approximately $280 \mathrm{~mm}$ by $215 \mathrm{~mm}$ in planform and $145 \mathrm{~mm}$ deep/thick. The weight is approximately $9 \mathrm{~kg}$. The interiors of the hollows are rough and show no signs of use. There is some shaping of the block by pecking, including the dished surface with the lower hollow in the illustration, while other facets appear unpecked and the result of breakage.

Given the character of this piece, and its association with a Beaker vessel in a pit, an interpretation as a double cup-marked stone is a distinct possibility. In this case a reasonably close parallel (though with shallower cups) would be provided by the double cup-marked sandstone block from the mound of a round barrow at Kilburn in North Yorkshire (Kinnes \& Longworth 1985, 90). Alternatively, it is possible that the two hollows relate to an intended but unfinished perforation. The reason for the perforation being abandoned could be that the block broke into an unsuitable form. The most obvious purpose for shaping and perforating a stone like this would, in that case, be to produce an upper quernstone, but this would assume the block was originally much larger and capable of being appropriately shaped, which is now impossible to determine, and would also imply a chronological mixture of Beaker and later artefacts within this feature, which is unlikely on stratigraphic grounds.

Stone block with a shallow hollow (SF 99, Area F, context 1105, illus 19). A roughly cylindrical block of an igneous porphyritic rock (buff-brown with red amphibole and green olivine phenocrysts) has been pecked to shape. The upper flat surface (illustrated) is smooth and has been used for some abrasive purpose, presumably grinding. It is flat apart from a small central dimple, $20 \mathrm{~mm}$ in diameter and of maximum depth $2 \mathrm{~mm}$. The lower surface is less flat and has an approximately central shallow hollow of maximum diameter $79 \mathrm{~mm}$ and depth $17 \mathrm{~mm}$. The surface within the hollow is smooth but with no trace of rotary motion. The block is roughly $320-350 \mathrm{~mm}$ in diameter and $170 \mathrm{~mm}$ deep/thick. The weight is approximately $38 \mathrm{~kg}$.

The lower hollow is obviously deliberate, the upper dimple could conceivably be the result of damage. Because the lower hollow is worn smooth it cannot be regarded as the beginning of an attempted perforation and its purpose, as does that of this object as a whole, remains obscure.

Stone block with large hollow (SF 100, Area F, context 1103, illus 20). A large block of sandstone, buff-brown in colour, is irregular in planform but has a flattish upper surface. This surface has a large U- to V-shaped hollow $200-210 \mathrm{~mm}$ in diameter and $145 \mathrm{~mm}$ deep. The hollow has been formed by coarse pecking, the marks from which are clearly visible for most of its depth. The bottom $20 \mathrm{~mm}$ or so of the hollow are worn completely smooth, but without any indication of rotary motion. Adjacent to the large hollow (both at $30 \mathrm{~mm}$ from its edge) are two small 

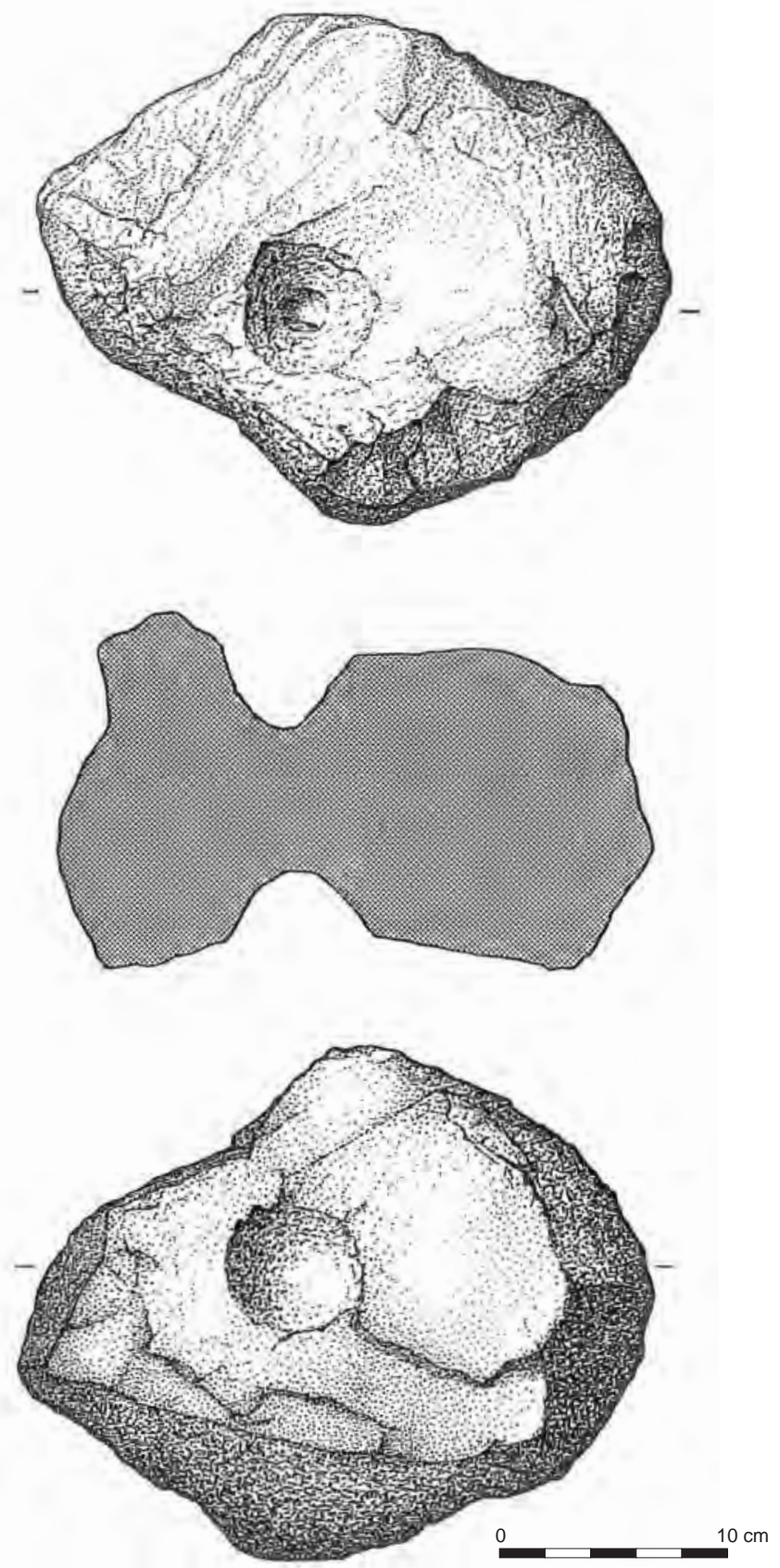

Illus 18 Stone block with two opposed hollows (SF 38)

drilled hollows, one $34 \mathrm{~mm}$ in diameter and $27 \mathrm{~mm}$ deep, the other $31 \mathrm{~mm}$ diameter and $27 \mathrm{~mm}$ deep. The interiors of these holes are worn smooth. The distance between the two small hollows is $140 \mathrm{~mm}$ centre to centre. The opposite surface or base is partly convex but otherwise irregular, and the block does not sit upright with the hollowed surface uppermost. The flattish surface with the hollows is approximately $470 \mathrm{~mm}$ by $410 \mathrm{~mm}$, and the block is $260 \mathrm{~mm}$ deep/thick. The weight is approximately $57 \mathrm{~kg}$.

Because there is no indication of rotary wear in the main hollow this cannot be a socket or pivot stone, and it seems more likely to be a kind of mortar.
However, the base of the large hollow is too narrow for it to have served as a grain mortar, for which a shallower or more cylindrical hollow is required. The two smaller holes suggest the possibility of being the seating for a cover or flap of some kind for the main hollow.

None of the four coarse stone objects is in itself conclusively diagnostic as to period, though in general terms the small, plain quernstone is unlikely to postdate the Iron Age and the double cup-marked stone would be appropriate to a Late Neolithic/Bronze Age context. There are no positive indications of metal tools having been used to work these stones and a prehistoric attribution is certainly most likely, 

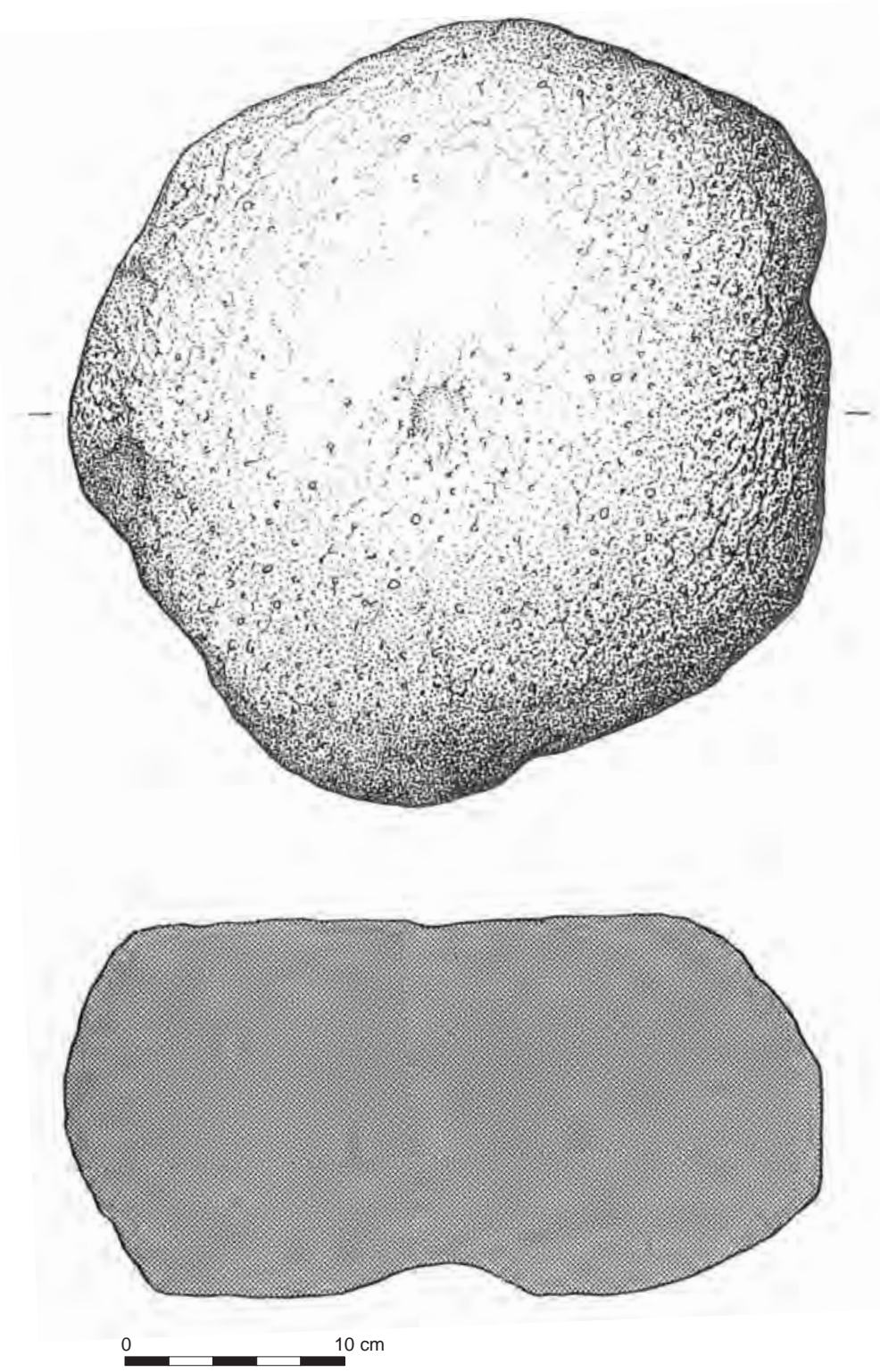

Illus 19 Stone block with hollow (SF 99)

though later manufacture cannot be entirely ruled out for those examples where the contextual association is ambiguous. The apparent absence from the site of the hammerstones used to work these stones, or the grinders used on the two with abraded surfaces, may hint that the contexts in which they were found bear no relation to their original manufacture and/or use. 


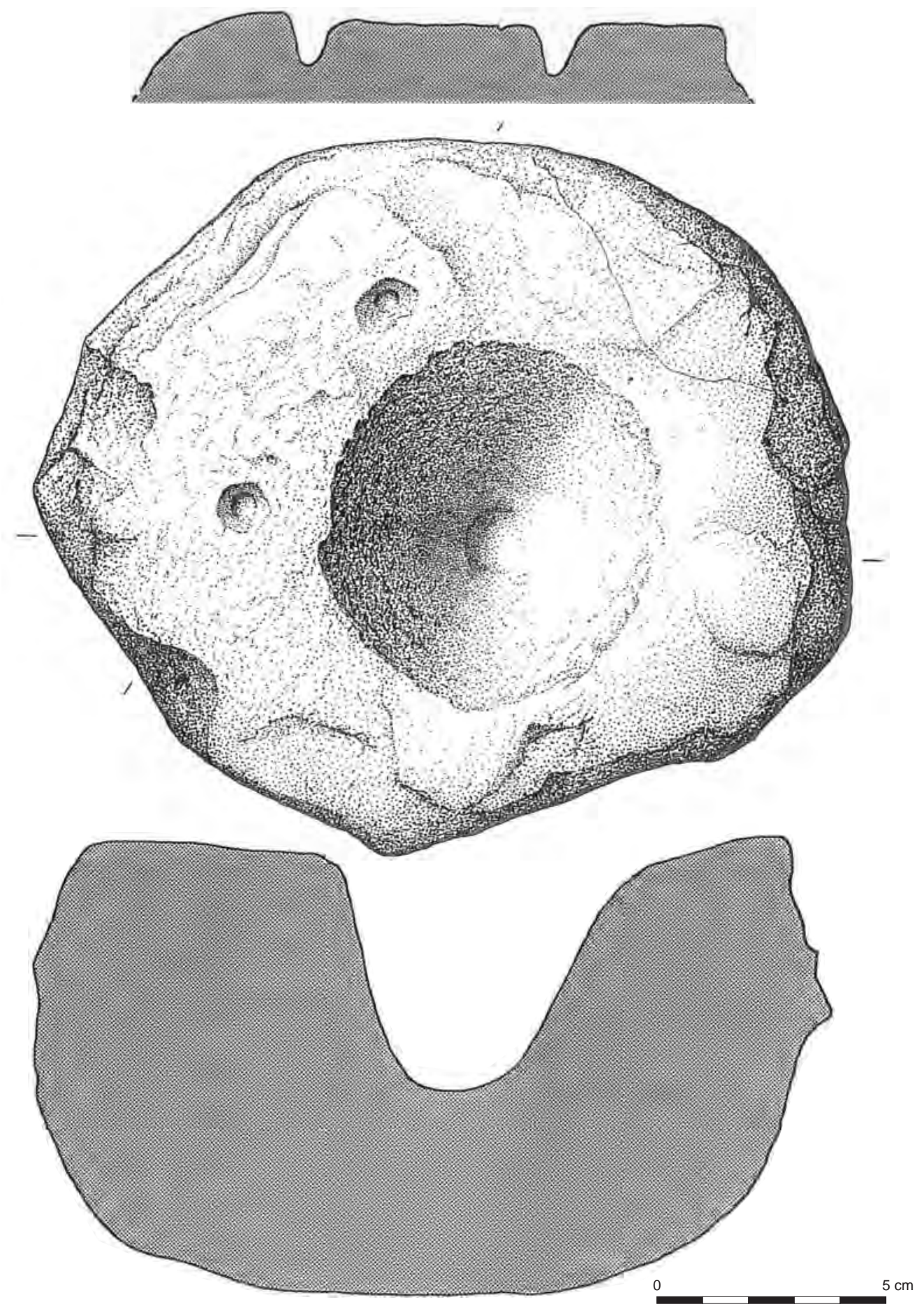

Illus 20 Possible mortar (SF 100) 


\section{The Pottery}

\subsection{Pottery of prehistoric and indeterminate date by Alison Sheridan \& Catherine McGill}

This was found in Areas B, C and F, and comprised:

- a plough-truncated, undecorated Early Bronze Age Beaker from Area B (SF 28)

- one near-intact coarse plain bucket-shaped pot from Area B (SF 40) of probable Late Bronze Age date (early 1st millennium $\mathrm{BC}$ )

- 35 sherds and several fragments from Areas B, C and F, mostly small and undiagnostic, but probably ranging from Early Neolithic to Iron Age date

- fragments of daub, of probable Iron Age date (SF 3), from Area B.

\subsubsection{Area B}

\section{Neolithic}

Four small body sherds (of which two conjoin to form a piece $45 \mathrm{~mm}$ by $33 \mathrm{~mm}$ ), together with a fragment and a crumb, from between one and three vessels (SFs 54, 55 \& 59; not illus). From fill of Pit 673 (context 649). All slightly abraded. These near-featureless body sherds would be hard to date on their own, but the fact that they come from a pit that has produced two fourth millennium radiocarbon dates (GU11071 and GU-11072, 3640-3360 and 3950-3660 cal $\mathrm{BC}$, respectively) suggests that they are Neolithic. The burnished finish, albeit crudely executed, on both surfaces of SF 55 and on the interior of SF 54 is consistent with an attribution to the Carinated Bowl ceramic tradition (Sheridan 1997; Sheridan 2003a). However, given the discrepancy between the dates and the otherwise undistinguished nature of the sherds, it is impossible to say whether they are of the earliest, 'traditional' kind of Carinated Bowl pottery or the later, 'modified' variety. Linear marks on both surfaces of these two sherds relate to the process of smoothing and burnishing, and do not represent deliberate decoration. The sherds have wall thicknesses up to $9 \mathrm{~mm}$. The conjoining sherds SF 55 and the sherd SF 59 are black throughout; the SF 54 sherd has a black interior and core and a pinkish-brown exterior. SF 55 has hackly fracture surfaces and uneven exterior and interior surfaces, interrupted by the stone temper inclusions. The latter are sparse (with a density of $c 5 \%$ ), rounded to angular, up to $c 4 \mathrm{~mm} \times 3 \mathrm{~mm}$ in size, and of more than one kind of stone. They include a black and white speckled crystalline stone, which may also be present in SFs 54 and 59.
Beaker (SF 28; illus 21; illus 22) From fill of truncated pit (context 507); associated with cupmarked stone (SF 38). Sherds from the rim, belly and base of an undecorated Beaker; much of one side is missing, through plough damage. The pot was tilting when discovered, but had probably been deposited upright. It contained densely packed sediment from the pit fill. The estimated height, rim diameter and base diameters are $c 160 \mathrm{~mm}, 158 \mathrm{~mm}$ and $c 92 \mathrm{~mm}$, respectively; the wall thickness ranges between 5.5 and $10.5 \mathrm{~mm}$. The rim is gently rounded; the neck short and splaying; the belly high and slightly globular; and the base flat on its exterior. (Its interior base shape cannot be determined.) The exterior and upper part of the interior surfaces are a light orange-brown, darkened in places by the recent application of a consolidant; the lower part of the interior is a medium-brown; and the core is blackish, indicating that the pot had been fired rapidly. There are no traces of any former contents. The surfaces have been smoothed and slipped, but fragments of the stone temper protrude, especially through the interior surface. The fabric tends to spall and has a hackly fracture. Inclusions occupy 10-15\% of the body and consist of angular fragments of a blackish-brown crystalline stone up to $6 \mathrm{~mm}$ by $8 \mathrm{~mm}$ in size. Overall, the pot is neither markedly fine nor markedly coarse in appearance.

In shape, the Beaker is comparable with Clarke's 'Developed Northern' (N2 or N3) types, and with a few 'Northern/North Rhine' (N/NR) examples (Clarke 1970). According to Lanting \& van der Waals' scheme, it can be ascribed to their 'step 4' (Lanting \& van der Waals 1972).

\section{Pottery of definite and probable Late Bronze Age date}

SF 40 Near-complete, undecorated, roughly bucketshaped coarseware pot (illus 23; illus 24). From fill of shallow pit (context 547), cut into the top of - and thus postdating - the trackway; there were no associated finds. The pit is close to two others that also post-date the trackway (contexts $758 \& 712$ ), with radiocarbon dates of $1130-830$ and 980-800 cal BC at 2-sigma, respectively (GU-11069 \& GU-11073). Just over a third of the rim is missing, and below the fracture edge a large part of the exterior surface has spalled off. The pot had been deposited upright, and it contained a hard-packed deposit of sediment from the pit fill, including some sizeable pebbles; there were no traces of any original contents. The height, rim and base diameters and wall thickness are $143 \mathrm{~mm}, 158 \mathrm{~mm}, c 100 \mathrm{~mm}$ and $10-13.5 \mathrm{~mm}$, respectively. The pot has a squared-off, internally-bevelled rim and a body that swells out slightly (and unevenly) from below the rim before narrowing (again unevenly) towards the base, forming a slight and discon- 


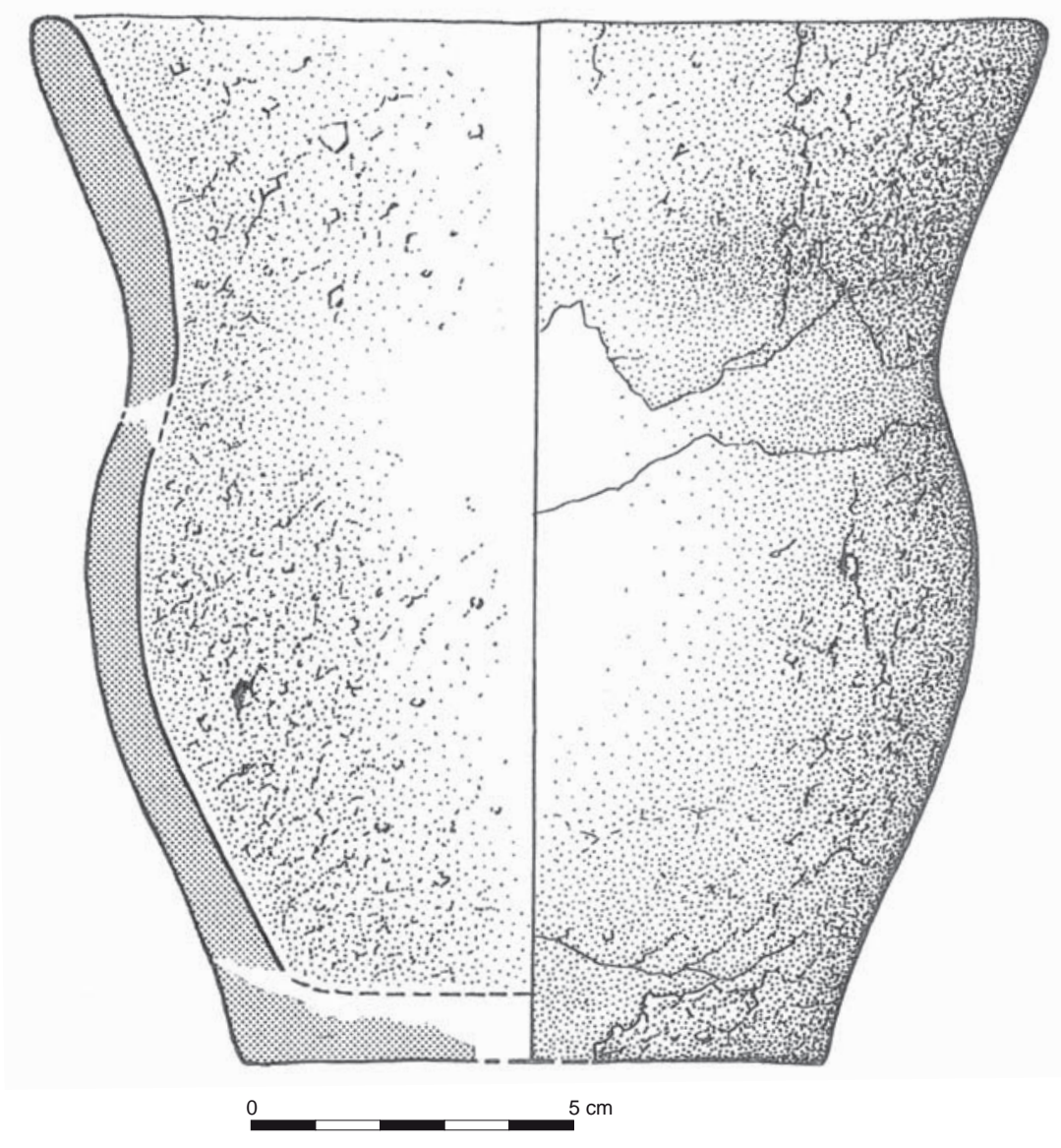

Illus 21 Beaker (SF 28)

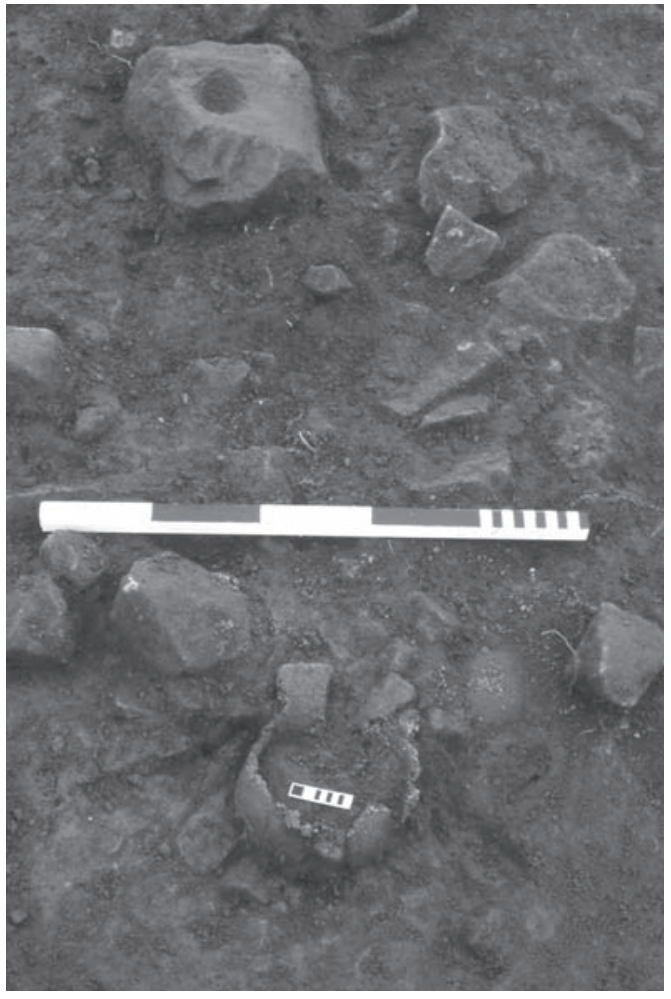

Illus 22 Beaker (SF 28) and stone object (SF 38) tinuous pedestal immediately above the base. The latter is slightly dished on the outside and convex on the inside. Although covered with a thick slip, the surfaces are very uneven, with roughly smoothed-down coil joints clearly visible on the interior surface, and many grits protruding through the surfaces. The exterior, which has hairline cracks, is a mottled medium and dark brown; the core and interior are blackish. The pot has fairly abundant ( $c$ 15$20 \%$ ) angular and sub-angular fragments, mostly of the black and white speckled crystalline stone as previously noted in SF 55; they range in size up to at least $17.5 \mathrm{~mm}$ by $13.5 \mathrm{~mm}$, and their angularity indicates that the stone had been deliberately crushed and added as temper.

SFs 68, 78, 80 \& 81 Rimsherd and three body sherds of similarly coarse pottery, probably from two vessels (illus 25). From the fill of a post-hole (context 826) cut into the fill of Pit 828. The rim (SF 68, estimated diameter $c$ 200mm; wall thickness $c 10 \mathrm{~mm}$ ) is flat and has a shallow bevel; below it, the body curves inwards. The surfaces, though slipped, are uneven, and the sherd edges are slightly abraded. Inclusions are sparse $(<5 \%)$ and small (up to $4 \mathrm{~mm} \times 2 \mathrm{~mm}$ ), and are of the speckled crystalline stone. Most of the external surface had spalled off from the body sherds, but where it survives the wall thickness is $13 \mathrm{~mm}$. The interior had been slipped or wet-smoothed. Inclusions comprise sparse but fairly large (up to $8 \mathrm{~mm} \times 5 \mathrm{~mm}$ ) angular and subangular fragments of black and brownish stone.

SF 64 Small, very slightly abraded rimsherd (illus 26) from pit fill (context 552, Pit 758), post-dating the 


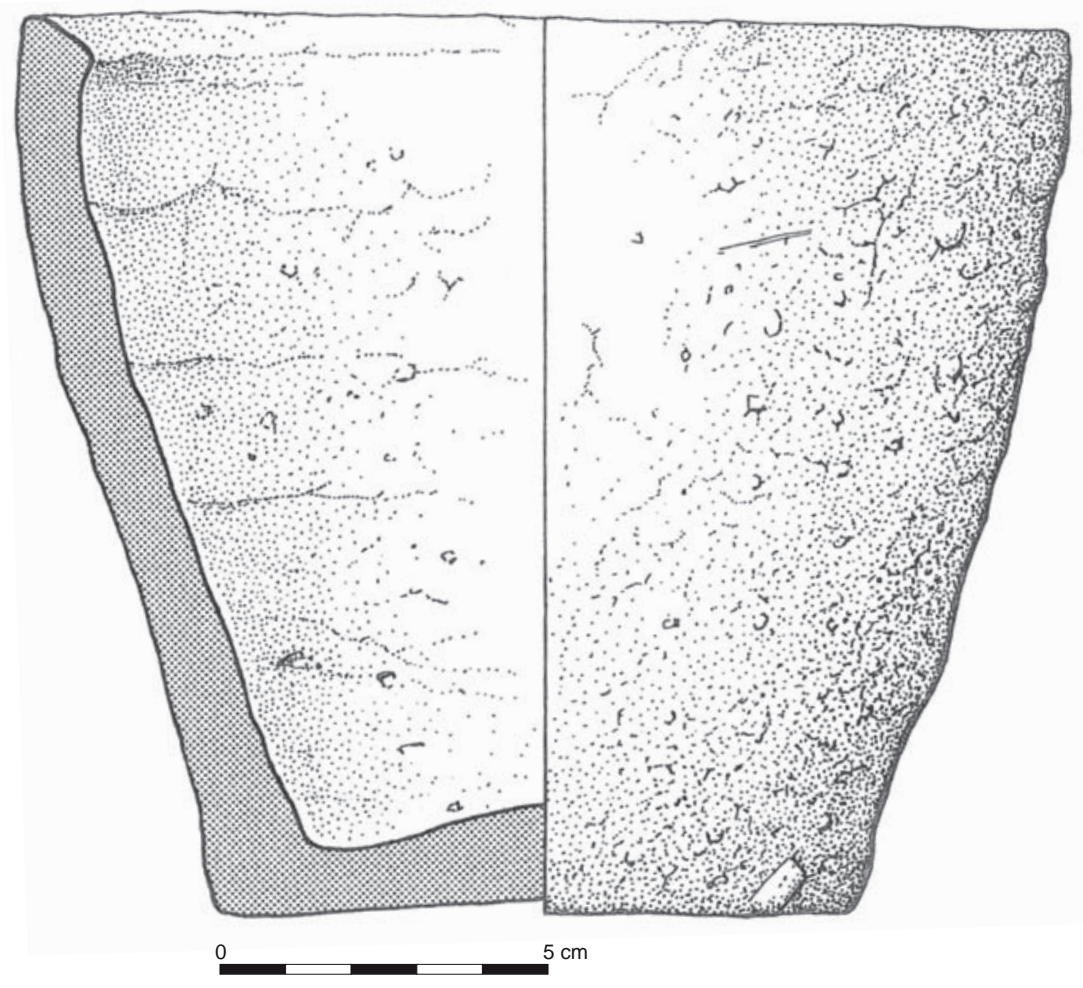

Illus 23 Bronze Age bucket-shaped pot (SF 40)

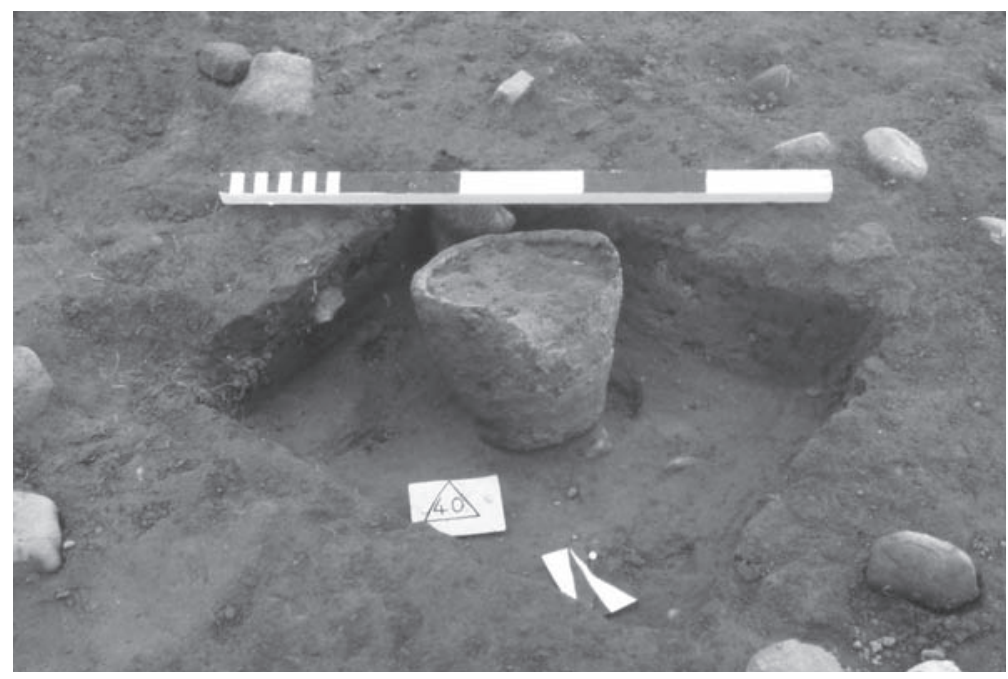

Illus 24 Bucket-shaped pot (SF 40) under excavation

trackway. Charcoal from this context produced the aforementioned date of 1130-890 cal BC (GU-11069), and this provides the basis for dating this sherd to the Late Bronze Age; otherwise, it could pass for Early Neolithic carinated pottery, although its small size $(28 \mathrm{~mm} \times 12 \mathrm{~mm})$ renders any definitive dating on stylistic grounds alone impossible. From a fairly fine-textured pot, with a wall thickness of $9 \mathrm{~mm}$ and hackly fracture surfaces; the sherd is too small to allow diameter estimation. The rim is very slightly rolled over and flattish. The surfaces have been smoothed to a low sheen; the exterior is pinkish-brown, the core greyish and the interior grey-brown. Inclusions comprise sparse $(<5 \%)$, fairly small (up to $4 \mathrm{~mm} \times 2 \mathrm{~mm}$ ), angular fragments of the speckled crystalline stone.

SF 65 Featureless body sherd (not illus) from the fill of one of the putative hearths near the southern edge of the trackway (context 718, Hearth 712). As with SF 64, the attribution of this sherd to the Late Bronze Age is based solely on the radiocarbon date of 980-800 cal BC at 2-sigma (GU-11073) obtained from charcoal in this fill. The sherd measures $35 \mathrm{~mm} \times 32 \mathrm{~mm}$, with a wall thickness of up to $9 \mathrm{~mm}$; the surfaces are uneven, and there are traces of a thin blackish encrustation on the exterior. Inclusions are 


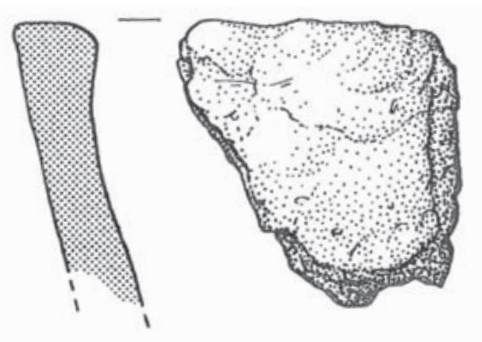

68

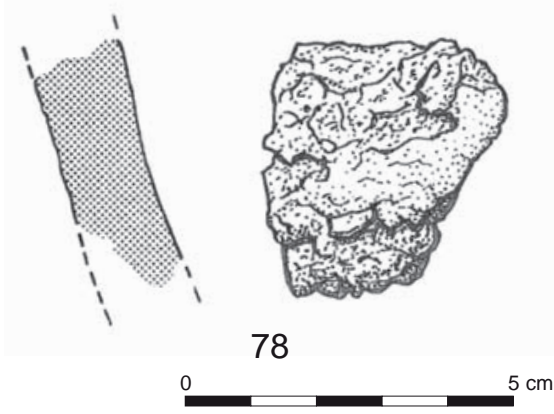

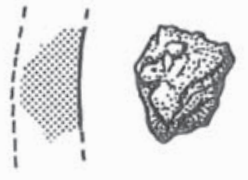

80

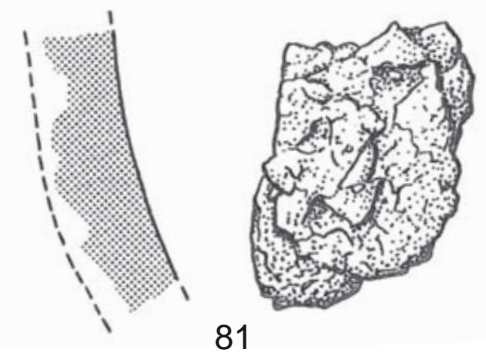

Illus 25 Rimsherd and three body sherds of probable Late Bronze Age coarse pottery

hard to discern, being the same grey-brown colour as the fabric, but appear fairly sparse.

\section{Pottery and daub of probable Iron Age date from in and near the 'banjo' feature}

SF 1 Rimsherd from a large flat-rimmed pot with an upright neck (illus 26) from the surface of the 'banjo' feature (context 009). The rim diameter had been at least $200 \mathrm{~mm}$, and the wall thickness $13.5 \mathrm{~mm}$. Although slightly uneven, the surfaces had been smoothed and slipped. The exterior and interior are medium brown, the core blackish. The inclusions comprise fragments of angular and sub-angular crushed stone of various kinds up to $c 10 \mathrm{~mm} \times 9 \mathrm{~mm}$ in size, and with a density of 7-10\%; they include the black and white speckly crystalline stone noted in other Maybury Park pottery, as well as a fine-grained blackish stone.

SF 2 Rimsherd from a thinner-walled (c 6mm), flatrimmed pot with upright neck (illus 26), from the same context. The rim is club-shaped and too small to permit diameter estimation. The colour varies throughout from pinkish-brown to blackish-brown. Inclusions comprise angular and sub-angular fragments of the speckly crystalline stone along with a fine-grained dark brown stone, up to $7 \mathrm{~mm} \times 5.5 \mathrm{~mm}$, at a density of $10-15 \%$.

SF 3 Lump of daub in several pieces (not illustrated, context 012), found adjacent to the 'banjo' feature. Soft, pinkish-brown, virtually inclusion-free clay. On one side they bear impressions of the ?wattlework structure against which the daub had been applied.

\section{Sherds of indeterminate date}

These comprise a rimsherd, a base sherd and five featureless body sherds.
SF 41 A small, abraded rimsherd (from colluvium, context 543; illus 26) from a fairly fine flat-rimmed pot. The wall thickness is $c 6 \mathrm{~mm}$; the surfaces brown and the core black. Inclusions are sparse $(<5 \%)$ but may include the speckly crystalline stone.

SF 29 A very abraded basal sherd (from topsoil, context 401 , not illustrated) from a fine, vessel of soft fabric.

SF 20 (not illustrated, from Trench 8 extension); SF 30 (from topsoil); SF 36 (from colluvium, context 543); SF 49 (from pit fill, context 550); and SF 52 (from stone-lined Pit 681) are featureless body sherds from coil-built pots. Little can be said about them other than that all but SF 36 are abraded to varying degrees, and that SF 36 contains fragments of the speckly crystalline stone.

\subsubsection{Area C}

\section{Probably and possibly Early Neolithic}

SF 82 Gently carinated sherd from a carinated bowl of probable Early Neolithic date (illus 26); stray find (context 1000). The sherd is $40 \mathrm{~mm} \times 32.5 \mathrm{~mm}$, with a wall thickness of $10-12 \mathrm{~mm}$ and an estimated carination diameter of $c$ $170 \mathrm{~mm}$. Its edges and interior surface have been abraded; the fabric is fairly soft. The exterior is smooth, but pitted where inclusions have fallen out. The exterior is black, the core and interior mid-brown. Inclusions are sparse (5-7\%) and small (up to $3 \mathrm{~mm} \times 2 \mathrm{~mm}$ ), varying in shape from round to angular; they include speckled crystalline grits similar to those seen in the other Maybury Park pottery.

SFs 69, 71, 72, 74, 76 Five featureless body sherds, with wall thicknesses between $8 \mathrm{~mm}$ and $11.5 \mathrm{~mm}$, abraded to varying degrees from the base of the colluvium (not illustrated, context 1002). SF 69 and SF 76 may belong to the same pot - a smooth-surfaced vessel, with tiny patches of blackish encrustation on the exterior surface 


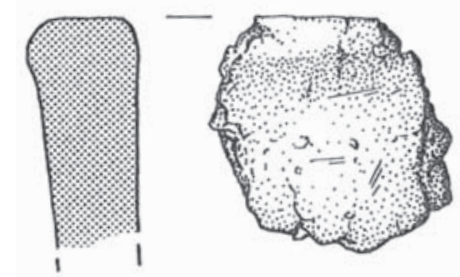

1

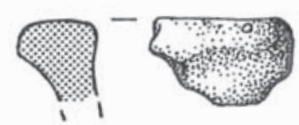

41
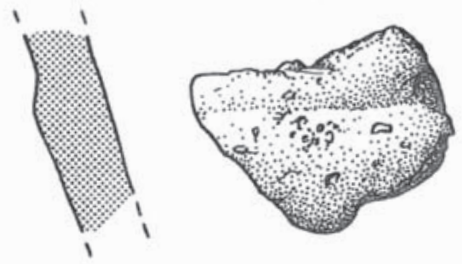

82

Illus 26 Probable Late Bronze Age property
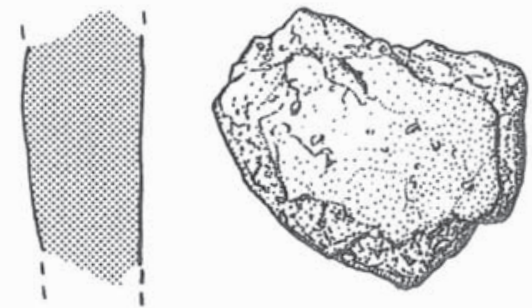

87
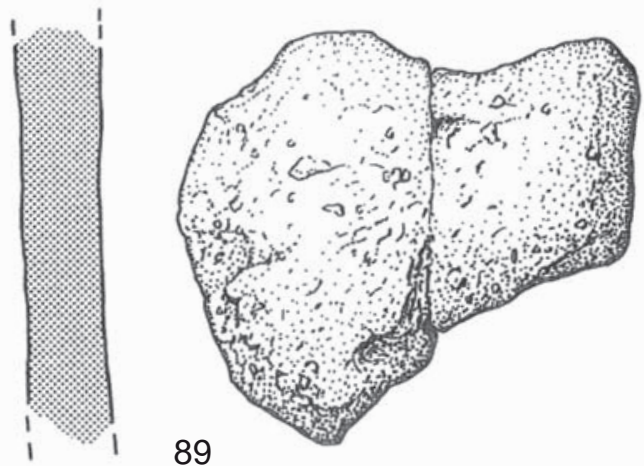

89
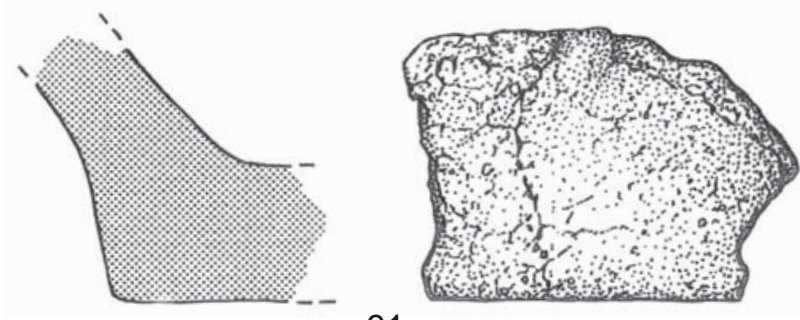

91

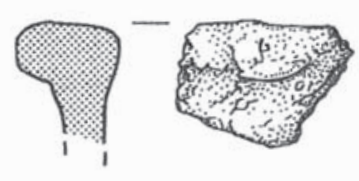

2

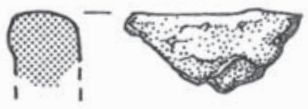

64

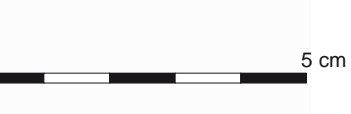

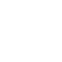


of SF 76 and inclusions, up to $8 \mathrm{~mm} \times 6 \mathrm{~mm}$ in size, of the speckled crystalline stone. Although they have no diagnostic features, an Early Neolithic date cannot be ruled out.

\subsubsection{Area $F$}

\section{Pottery of Iron Age (and possibly later) date from the stone structure}

Sherds of four pots were found at various depths in the fills of the hollow.

\section{SFs 87 \& 89 (context 1101); SF 91 (context 1102)}

Three soft, abraded body sherds (of which two are now conjoined) and a wall-and-base sherd from a large, undecorated, thick-walled coarseware pot (illus 27). The pot had a flat, pedestalled base above which the wall splayed. The estimated base diameter is $c 200 \mathrm{~mm}$; wall and base thicknesses are $11.5-17.5 \mathrm{~mm}$ and $21 \mathrm{~mm}$, respectively. The largest sherd is $75 \mathrm{~mm} \times 60 \mathrm{~mm}$. The exterior surface is a mottled orange-brown, pale and dark grey and black; the core blackish; the interior orange. The surfaces are uneven, and SF 91 has hairline cracks on both its interior and exterior. Inclusions are relatively sparse (c 7\%) and mainly comprise angular and sub-angular fragments of the speckled crystalline stone up to $5 \mathrm{~mm} \times 4.5 \mathrm{~mm}$. Some small reddish, iron-rich(?) inclusions are also present in SF 87.

SF 97 Body sherd (not illustrated, context 1130), 50mm $\times 35 \mathrm{~mm}$, from just above the base of a coarse, flat-based pot, from the basal silt. The sherd had broken along a coil joint line at the junction of the base and wall; the latter rises with a very slight splay from the base, suggesting that the pot had probably been bucket-shaped. The pot's estimated diameter at this point is $c 160 \mathrm{~mm}$; wall thickness is $c 12 \mathrm{~mm}$. The exterior is a purplish-brown, and the core and interior are black. The fabric is hard and the surfaces slightly uneven, with grits protruding. Inclusions comprise sub-angular and angular fragments of the speckled crystalline stone up to $c 7 \mathrm{~mm} \times 6.5 \mathrm{~mm}$, at a density of $10-15 \%$

SF 88 Heavily abraded fragment, $16.5 \mathrm{~mm} \times 13 \times 9 \mathrm{~mm}$ (not illustrated, context 1102). Mottled orange and dark grey throughout. Contains one inclusion of the speckled crystalline stone.

SF 93 Burnt and abraded curving body sherd, $37 \mathrm{~mm} \times$ $34 \mathrm{~mm} \times 10 \mathrm{~mm}$ (not illustrated, context 1120). Buff-orange throughout, with a dark grey encrustation on the exterior. Soft, fine, no inclusions visible.

\subsubsection{Discussion}

This small assemblage reflects the chronological diversity of the activities attested at Maybury Park; and the recurrent presence of a particular kind of stone as temper, in pottery from different periods, suggests that most, if not all, of the pottery had probably been made locally. (Geological sourcing of the stone would, however, be required to verify this.)

The ten small sherds of probable and possible Neolithic date from Areas B and C are not particu- larly informative as regards the nature of Neolithic activities at Maybury Park; but the carination sherd SF 82 appears to belong to the Early Neolithic Carinated Bowl tradition, whose dating is consistent with the dates (GU-11071-2) obtained from the fill of the oval Pit 673, which also produced Carinated Bowl pottery (see Sheridan 1997 and Sheridan 2003a on the dating of this pottery in Scotland).

The Beaker is scarcely more informative as to its circumstances of deposition - and the severe ploughtruncation of the large oval pit in which it was found hinders interpretation. The size and shape of the pit would be consistent with it being a grave pit, but no trace of human bone was found; indeed, the presence of several large lumps of charcoal adjacent to the Beaker is puzzling. Furthermore, Clarke has pointed out that undecorated Beakers are relatively rare in funerary contexts (Clarke 1970, appendix 7.20). Unfortunately, it is not currently possible to allocate the Beaker to a date range narrower than $c$ 2600-1800 BC (Kinnes et al 1991) - a situation that may eventually be remedied through new dating programmes such as the one currently underway for the National Museums of Scotland. However, the date of 2310-1950 cal BC at 2-sigma (GU-11070), obtained from a disturbed hearth around $19 \mathrm{~m}$ to the south-east, is further evidence for Beaker period activity and might indirectly provide a date for the Beaker in the pit.

The flat-based coarse vessels from Area B are of particular interest because, despite their superficial homogeneity, they appear to span at least a millennium. Four pots (detailed above) probably date to c 1000-800 BC (in line with the radiocarbon dates obtained from Features 552 and 718 in Area B, ie GU-11069 and GU-11073, respectively), while the pottery from the 'banjo' feature in Area B and from the structure in Area F is likely to date from the centuries around the time of Christ (in line with the date GU-11074 from Area F).

The flat-based and flat-rimmed undecorated coarseware of the Bronze and Iron Ages is notoriously difficult to date on stylistic grounds and has been the subject of some debate. In his discussion of the late second to early first millennium BC assemblage from Ormiston Farm, Fife, Halliday (Halliday 1988) proposed the abandonment of Coles \& Taylor's term 'Flat-rimmed Ware' (Coles \& Taylor 1970, 978) to describe this kind of pottery, as it implies an unwarranted unity of tradition. The same could be said for the term 'bucket urn' to refer to flat-rimmed coarse pots from Bronze Age funerary contexts, whose currency appears to span up to a millennium from $c 1700 \mathrm{BC}$ to at least $800 \mathrm{BC}$ (Sheridan 2003b, 210-13). The formal simplicity of flat-based undecorated coarseware has led several commentators (eg McLellan 1992) to suggest that it is unlikely to show chronological or regional patterning. However, as Halliday and others (eg Cool 1982; Burgess 1995) have suggested, this may not be the case This position is vindicated by the doctoral research carried out by one of us (CMcG), which has succeed- 


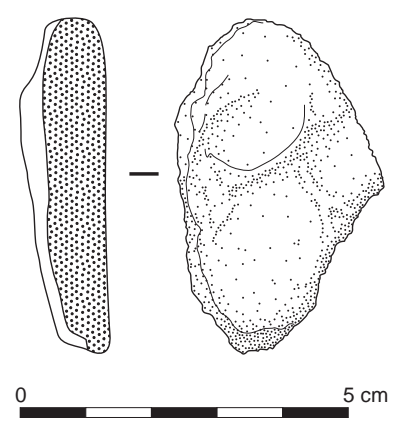

Illus 28 Possible Post-Roman pottery

ing in teasing out some such patterning, however subtle.

The four probable Late Bronze Age pots can be parallelled in shape, size and fabric among funerary and domestic pottery dating to between the 13 th and 9 th centuries BC. This includes:

1 The assemblage relating to secondary, funerary activity at Old Keig recumbent stone circle in Aberdeenshire (Childe 1933, 44; Childe 1934, $386-8)$, recently dated to $2820 \pm 50$ вР (1130-830 cal BC at 2-sigma, GrA-21696: Sheridan 2003b).

2 The urn from Duff House, Banff, which looks like a slenderer version of Maybury pot SF 40 and is dated, through its associated gold jewellery, to around the 13th century BC (Eogan 1994, 75-7).

3 The Late Bronze Age domestic assemblage from Myrehead, Falkirk, dating to between 1260 and 810 cal вС $(2825 \pm 85$ вP, GU-1608; $2830 \pm 60$ вР, 1190-830 cal BC at 2-sigma, GU-1609: Barclay 1983, SFs 6, 9 \& 10; cf in particular SF 6 with Maybury SF 68).

4 The aforementioned domestic assemblage from Ormiston Farm (Sherriff 1998), dated to $2935 \pm 60$ BP (1370-940 cal BC at 2-sigma, GU1669). A further example of coarseware, from Claish, Stirling - albeit coarser in fabric than the Maybury material - has recently been radiocarbon dated to $3005 \pm 35$ BP (1380-1120 cal BC at 2-sigma, AA-49634: Sheridan 2003a, illus 20).

As for the pottery of probable and possible Iron Age date, the date of $2020 \pm 50$ BP (170 cal BC-cal AD 80, GU-11074) from the structure in Area $F$ provides the basis for dating this pottery; there is no reason to believe that the sherds in question were residual from an earlier period of activity. The base sherd with its splaying wall (SF 91) invites comparison with a near-complete bucket-shaped pot from Myrehead
(Sheridan 2003a, SF 15), from a context dating to $1885 \pm 60$ BP (cal BC/AD 0-cal AD 320, GU-1610). As for sherds SF 1 and SF 2 from the 'banjo' enclosure in Area B, general similarities in form and fabric are to be found among assemblages such as Traprain Law (eg Curle 1915, figs 11-13; Curle \& Cree 1921, fig 13; McGill forthcoming a), Kaimes Hill (Simpson 1969), Cardean (McGill forthcoming b) and the souterrains in Angus and Perth \& Kinross (eg Shanzie: McGill 2002; McGill forthcoming c; McGill forthcoming d), so perhaps a date in the late first millennium $\mathrm{BC}$ to early first millennium AD can be proposed. Uprightrimmed pots with wall thicknesses comparable to that of SF 1 tend to appear on Late Iron Age settlement sites such as Traprain Law and Enochdhu (RCAHMS 1990).

\subsection{Post-Roman pottery by John A Lawson}

A tiny buff body sherd $(32 \mathrm{~mm} \times 14 \mathrm{~mm} \times 6 \mathrm{~mm}$ at its maximum) with a slightly paler oxidized surface. A sandy/gritty fabric rich in quartz inclusions and some unidentified black rock fragments. The quartz varies from opaque to a pinkish brown in colour with the grains varying in size up to $c 2 \mathrm{~mm} \times 2 \mathrm{~mm} \times$ $4 \mathrm{~mm}$. What is almost certainly the exterior surface is decorated with what may possibly be a thin applied $c 8 \mathrm{~mm}$ broad. This strip has been impressed to form what maybe a row of shallow slightly random oval impressions $6 \mathrm{~mm} \times 8 \mathrm{~mm}$. Due to the small size of the shard it is not possible to ascertain if this decoration is vertical or horizontal. Context 103, Area F, illus 28.

This sherd does not fit within any known Scottish ceramic groupings, being rejected by prehistorians (A Sheridan, pers comm), Romanists (F Hunter, pers comm) and medievalists (G Haggarty, pers comm). This might suggest a possible later first millennium $\mathrm{AD}$ date and would benefit from being compared to the Scottish Redware database, and in particular with the Anglian loomweights excavated from South Platt hill near Ratho (Norton \& MacSween 1995).

\subsection{Post-medieval pottery by Valerie E Dean \& John A Lawson}

A small assemblage of domestic post-medieval pottery was recovered from areas B, F and U. The assemblage consisted of four sherds of Scottish post-medieval Reduced Ware and three sherds of Scottish post-medieval Oxidized Ware dating to the 16th-17th centuries. 


\section{The Carbonized Remains by Mhairi Hastie}

\subsection{Introduction}

During the excavations, bulk soil samples and a number of 'special' samples (primarily fragments of charcoal) were taken for palaeo-environmental analysis.

The samples were processed and assessed by Sheila Boardman in 1994. The sample fractions not sorted during the assessment stage were submitted to Headland Archaeology in 2002 for further postexcavation analysis. Plant remains removed from the samples and previously identified by Sheila Boardman were lost during the interim period. Consequently, further analysis could not be carried out on this material.

The following report concentrates on the carbonized plant remains. The summary tables amalgamate the results from the sample assessment as identified by S Boardman (Banks \& Boardman 1995), with the carbonized plant remains removed and identified from the available sample fractions not originally sorted during the assessment stage.

A mixture of cereal, weed seeds/fruits, flax seeds and hazelnut shell were recovered from a number of the samples albeit in low quantities. The presence of naked barley, hulled barley and emmer grain is consistent with the prehistoric date for the site indicated by pottery recovered from a number of the archaeological features.

The absence of any high concentrations of cereal remains suggests that most was not charred in situ. The plant material recovered is likely to represent the remnants of food/grain burnt during food processing or corn drying that had been reworked and redeposited across the site.

\subsection{Results}

\subsubsection{Distribution}

A mixture of carbonized plant remains, including cereal grains, seeds/fruits of wild taxa and one chaff fragment, were recovered, although no samples contained more than 15 identifiable cereal grains.

Seven areas (A, B, C, D, E and U) were excavated during the fieldwork. Carbonized plant remains were recovered from three of these areas $-\mathrm{B}, \mathrm{C}$ and $\mathrm{F}$ - the bulk of which were in Area B.

\subsubsection{Cereal remains}

The most commonly encountered element was carbonized cereal grain including hulled barley (Hordeum vulgare), naked barley (Hordeum vulgare var nudum) and wheat tentatively identified as emmer wheat (Triticum cf dicoccum). In addition, one emmer glume base fragment was recovered from context 698 [Area B: burnt deposit (context 699)] and one barley internode was recovered from Context 1102 [Area F: shallow scoop (context 1130)].

\subsubsection{Weed seeds}

Small quantities of seeds/fruits of wild taxa were recovered from a number of samples including: Bilderdykia convolvulus (black bindweed), Carex spp (sedge), cf Aphanes sp (parsley piert), Rumex spp (dock), Chenopodium album (fat hen), Polygonum sp (knotgrass), Spergula arvensis (corn spurrey), Stellaria media (corn marigold), Brassica cf rapa (white cabbage/mustard) and Gramineae indet (grass family). In addition, one grain and one tuber of Arrhenatherum sp (oat-grass) were also recovered.

\subsubsection{Potential economic species}

Two seeds of cultivated flax (Linum usitatissumum) were recovered from context 460 [Area B: burnt deposit (context 715)] and low quantities of hazelnut shell (Corylus avellana) were recovered from contexts 547, 649 and 671 (all from Area B).

\subsection{Discussion}

\subsubsection{Concentration and distribution}

The quantity of plant remains is low and there is no evidence for any in situ burning. In all cases it is unlikely that the plant material relates to the original function of the feature from which they were recovered.

The lack of any obvious conflagration deposits within the excavated areas suggested that the plant remains area likely to be remnants of food or grain burnt during preparation/cooking activities or small-scale corn drying, and then reworked or re-deposited across the site. The slight increase in plant remains, particularly from pit fills in Area B, may suggest that the burnt grain or food debris was being dumped in the pits along with other rubbish.

\subsubsection{Plant assemblages}

The plant assemblages consisted principally of cereal grain and seeds/fruits of wild taxa with occasional 
fragments of charred hazelnut shell and two flax seeds. The recovery of both naked and hulled barley along with emmer grain corresponds well with the archaeological evidence indicating a prehistoric date for the features.

The quantity of weed seeds/fruits and other plant remains recovered was low, limiting the potential for discussion of these remains. The wild taxa present are commonly associated with cultivated land or waste places and were probably brought to the site via clothing, tools and with the harvested crops.

Hazelnut shell and flax seeds have been recovered from other prehistoric sites and the recovery of such remains at Maybury, albeit in low quantities, fits a well-established pattern. The low quantities recovered, however, are not sufficient to allow detailed discussion.

\subsection{Summary}

- A limited amount of carbonized plant remains were recovered from the site.

- The majority of plant remains were recovered from Area B with pit fills containing slightly larger average quantities of plant remains.

- The presence of naked barley, hulled barley and emmer cereal grains corresponds well with the prehistoric date indicated by pottery recovered from a number of the archaeological features.

- There is no evidence for in situ burning of plant remains and the material is unlikely to be associated with the original function of the features from which they were recovered.

- The lack of any obvious conflagration deposits within the excavated areas suggests that the plant material recovered is probably remnants of grain accidentally burnt during food processing or corn drying. 


\section{Conclusion}

It is difficult to interpret the nature of human activity in the area with the available evidence although some broad assumptions can be made. The area was settled at the beginning of the Neolithic period and occupied sporadically since. It is probable that the land was put to agricultural use with settlement on the edge of the Gogar Loch between Areas B and C. It is likely that animal husbandry was important in the Neolithic as indicated by the trackway. The edge of the loch would have been an excellent environment for fishing and fowling, which would have supplemented agriculture throughout the prehistoric period. The segmented enclosure system may have served as stock enclosures later in the prehistoric period. Evidence for habitation was scant but evidence was recovered for temporary settlement in the Neolithic, with more permanent settlement in the Bronze/Iron Age. The stone structure identified in Area $\mathrm{F}$ is an unusual feature and likely to be of either industrial or ritual function; it is very difficult to assign a domestic function to it on the available evidence. A possible cist and a number of possible funerary pits were identified in Areas A
(Phase II) and B (Phase II), although it is difficult to confirm this without the presence of human bone. If these features do represent human burials they are likely to represent isolated burials adjacent to settlement.

While significant archaeological deposits were recorded in the areas excavated, particularly areas $\mathrm{B}$ and $\mathrm{F}$, it was unfortunate that it was not possible to open much more extensive areas. The evaluation, while extensive for its day (in Scotland), represented less than $0.5 \%$ of the surface area of the site which would be considered grossly inadequate in modern (post-1994 publication of NPPG5) archaeological practice, where a 5\% sample area is the norm. The results of the excavations appear to indicate that the areas investigated were located at the periphery of more intense foci of activity. It is recognized that, with hindsight, and in a modern development context, a more robust sampling strategy would have been pursued initially and that the entire development site would have been subjected to a more exhaustive programme of works including the stripping and excavation of much larger areas. 


\section{Acknowledgements}

The Maybury Park project was undertaken by the City of Edinburgh Council Archaeology Service (CECAS) under the management of Mark Collard between 1990 and 1992. As a result of a number of key staff leaving that organization, the final postexcavation analysis was undertaken jointly by Headland Archaeology Ltd and CECAS. The work was funded jointly by Edinburgh City Council and Historic Scotland. The authors would also like to thank all those who worked on the site.

Alan Saville would like to thank Professor Alexander Fenton and Trevor Cowie for advice on the coarse stone items and Dr Suzanne Miller for their geological identification. 


\section{References}

Alexander, D \& Watkins, T 1998 'St Germains, Tranent, East Lothian: the excavation of Early Bronze Age remains and Iron Age enclosed and unenclosed settlements', Proc Soc Antiq Scot $128,203-54$.

Ballin Smith, B (ed) 1994 Howe: Four Millennia of Orkney Prehistory, Excavations 1978-1982. Edinburgh (Soc Antiq Scot monogr ser 9).

Banks, I \& Boardman, S 1995 Maybury Park soils post-excavation analysis. Glasgow University Archaeology Research Division Report 97. Glasgow, GUARD.

Barclay, G J 1983 'The excavation of a settlement of the Later Bronze Age and Iron Age at Myrehead, Falkirk District', Glasgow Arch J 10, 41-71.

Bishop, M (ed) 2002 Roman Inveresk, Past, Present and Future. Chirnside, The Armatura Press.

Boardman, S 1994 Assessment of Bulk Samples and Charcoal Samples from Maybury Park Edinburgh. Edinburgh, report by EASE Archaeology.

Burgess, C 1995 'Bronze Age settlements and domestic pottery in northern Britain: some suggestions', in Kinnes, I A \& Varndell, G (eds) 'Unbaked Urns of Rudely Shape', 145-58. Oxford (Oxbow monogr 55).

Childe, V G 1933 'Trial excavations at the Old Keig stone circle, Aberdeenshire', Proc Soc Antiq Scot 68 (1933-4), 37-53.

Childe, V G 1934 'Final report on the excavation of the stone circle at Old Keig, Aberdeenshire', Proc Soc Antiq Scot 68 (1933-4), 372-93.

Clarke, D L 1970 Beaker Pottery of Great Britain and Ireland. Cambridge.

Coles, J M \& Taylor, J J 1970 'The excavation of a midden in the Culbin Sands, Morayshire', Proc Soc Antiq Scot 102 (1969-70), 87-100.

Collard, M 1996 'Cultins Road field evaluation' Discovery Excav Scot 1996, 38-9.

Cool, H E M 1982 'The artefact record: some possibilities', in Harding, D W (ed), Later Prehistoric Settlement in South-East Scotland, 92-100. Edinburgh, Edinburgh University Press.

Cook, M 2000 'Excavation of Neolithic and Bronze Age settlement features at Lamb's Nursery, Dalkeith, Midlothian', Proc Soc Antiq Scot 130, 93-113.

Cook, M 2004 'Howe Mire: excavations across the cropmark complex at Inveresk, Musselburgh, East Lothian', Proc Soc Antiq Scot 134, 131-60.

Curle, A O 1915 'Account of the excavations on Traprain Law in the parish of Prestonkirk, County of Haddington, in 1914', Proc Soc Antiq Scot 49 (1914-15), 139-202.

Curle, A O \& Cree, J E 1921 'Account of the exca- vations on Traprain Law during the summer of 1920', Proc Soc Antiq Scot 55 (1920-1), 153-206.

Driscoll, S T 1997 'A Pictish settlement in north-east Fife: the Scottish Field School of Archaeology excavations at Easter Kinnear', TAFAJ 3, $74-118$

Eogan, G 1994 The Accomplished Art. Oxford, Oxbow Books.

Haggerty, G 1980 'Pottery', in Ewart, G 'Excavations at Stirling Castle 1977-8', Post-Medieval Archaeol 14, 36-46.

Hanson, W S 2002 'Amongst the field systems I: Monktonhall', in Bishop, M (ed) 2002, 52-61.

Halliday, S 1988 'The pottery', in Sherriff, J R 'A hut circle at Ormiston Farm, Newburgh, Fife', Proc Soc Antiq Scot 118, 104-8.

Haselgrove, C \& McCullagh R 2000 An Iron Age Coastal Community in East Lothian: The Excavation of two Later Prehistoric Enclosure Complexes at Fishers Road, Port Seton, 1994-5. Edinburgh (STAR monogr 6).

Jones, E 2002 'Cultins Road', Discovery Excav Scot $2002,47-8$.

Kinnes, I A \& Longworth, I H 1985. Catalogue of the Excavated Prehistoric and Romano-British Material in the Greenwell Collection. London, British Museum Publications.

Kinnes, I A, Gibson, A, Ambers, J, Bowman, S, Leese, M \& Boast, R 1991 'Radiocarbon dating and British Beakers: the British Museum programme', Scott Arch Rev 8, 35-68.

Lanting, J N \& van der Waals, J D 1972 'British Beakers as seen from the Continent', Helinium $12,20-46$.

Malone, C 2001 Neolithic Britain and Ireland. Stroud, Tempus.

Maxwell, G 1984 'Gogar Roman Temporary Camp', Discovery Excav Scot 1984, 16.

McCullagh, R P J \& Tipping, R 1998 The Lairg Project 1988-1996: The Evolution of an Archaeological Landscape in Northern Scotland. Edinburgh (STAR monogr 3).

McGill, C 2002 'Prehistoric pottery', in Coleman, R \& Hunter, F J, 'The excavation of a souterrain at Shanzie Farm, Alyth, Perthshire', Tayside Fife Arch $J$ 8, 90 \& 94.

McGill, C forthcoming a 'The pottery', in Armit, I, Dunwell, A \& Hunter, F J, 'Report on excavations on the summit of Traprain Law'.

McGill, C forthcoming b 'Prehistoric pottery', in Hoffman, B, 'Report on excavations at Cardean'.

McGill, C forthcoming c 'The pottery', in Alexander, D, 'Report on excavations at Red Castle, Angus'. 
McGill, C forthcoming d 'The pottery', in Rees, A, 'Report on the excavations at Hawkhill, Angus'.

McLellan, V J 1992 'Coarse wares', in Rideout, J S, Owen, O \& Halpin, E, Hillforts of Southern Scotland, 48-9. Edinburgh (STAR monogr).

Moloney, C, Holbrey, R, Wheelhouse, P \& Roberts I 2003 Catterick Racecourse, North Yorkshire: The reuse and adaptation of a monument from prehistoric to Anglian times. Leeds (Archaeological Services (WYAS) Publications 4).

New Statistical Account of Scotland 1845, Vol 1.

Norton A \& MacSween A 1995 'The loomweights', in Smith A N 1995, 106-8.

O’Sullivan, J 1998 'The architecture of prehistoric settlement at Lairg', in McCullagh, R P J \& Tipping, R The Lairg Project 1988-1996: The Evolution of an Archaeological Landscape in Northern Scotland. Edinburgh (STAR monogr 3).

Piggott, C M 1948 'The excavations at Hownam Rings, Roxburghshire, 1948', Proc Soc Antiq Scot 82 (1947-8), 193-225.

Pryor, F 1998 Farmers in Prehistoric Britain. Stroud, Tempus.

Raisen, P \& Rees, T 1995 'Excavations of three cropmark sites at Melville Nurseries, Dalkeith', Glasgow Archaeol J, 19, 31-50.

RCAHMS 1990 The Royal Commission on the Ancient and Historical Monuments of Scotland. North-east Perth: an Archaeological Landscape. Edinburgh, RCAHMS.
Roberts, I, Burgess, A \& Berg, D 2001 A New Link to the Past: The Archaeological Landscape of the M1-A1 Link Road. York (Yorkshire Archaeology monogr 7).

Sheridan, J A 1997 'Pottery', in Johnston, D A, 'Biggar Common, 1987-93: and early prehistoric funerary and domestic landscape in Clydesdale, South Lanarkshire', Proc Soc Antiq Scot 127, 202-23.

Sheridan, J A 2003a 'Pottery and other ceramic finds', in Barclay, G J, Brophy, K \& McGregor, G, 'Claish, Stirling: an early Neolithic structure in its context', Proc Soc Antiq Scot 132, 79-88.

Sheridan, JA 2003b 'New dates for Scottish Bronze Age cinerary urns: results from the National Museums of Scotland Dating Cremated Bones Project', in Gibson, A (ed) Prehistoric Pottery: People, Pattern and Purpose, 201-26. Oxford (Br Archaeol Rep, Int Ser 1156).

Sherriff, J 1988 'A hut-circle at Ormiston Farm, Newburgh, Fife', Proc Soc Antiq Scot 118, 99-110.

Smith, AN 1995 'The excavation of Neolithic, Bronze Age and Early Historic features near Ratho, Edinburgh', Proc Soc Antiq Scot 125, 69-138.

Simpson, D D A 1969 'Excavations at Kaimes Hillfort, Midlothian, 1964-1968', Glasgow Archaeol J 1, 7-28.

Watkins, T 1980 'Excavation of an Iron Age open settlement at Dalladies, Kincardineshire' Proc Soc Antiq Scot 110, 122-64. 